\title{
Enterobactin Protonation and Iron Release: Structural Characterization of the Salicylate Coordination Shift in Ferric Enterobactin
}

\author{
Rebecca J. Abergel ${ }^{\dagger}$, Jeffrey A. Warner ${ }^{\ddagger}$, David K. Shuh ${ }^{\ddagger}$, and Kenneth N. Raymond ${ }^{\dagger, \ddagger}{ }^{\star}$ \\ tContribution from the Department of Chemistry, University of California, Berkeley, CA \\ 94720-1460 \\ ${ }^{\ddagger}$ Chemical Sciences Division, Lawrence Berkeley National Laboratory, Berkeley, CA 94720
}

\section{Abstract}

The siderophore enterobactin (Ent) is produced by many species of enteric bacteria to mediate iron uptake. This iron scavenger can be reincorporated by the bacteria as the ferric complex $\left[\mathrm{Fe}^{\mathrm{III}}(\mathrm{Ent})\right]^{3-}$ and is subsequently hydrolyzed by an esterase to facilitate intracellular iron release. Recent literature reports on altered protein recognition and binding of modified enterobactin increase the significance of understanding the structural features and solution chemistry of ferric enterobactin. The structure of the neutral protonated ferric enterobactin complex $\left[\mathrm{Fe}^{\mathrm{III}}\left(\mathrm{H}_{3} \mathrm{Ent}\right)\right]^{0}$ has been the source of some controversy and confusion in the literature. To demonstrate the proposed change of coordination from the tris-catecholate $\left[\mathrm{Fe}^{\mathrm{III}}(\mathrm{Ent})\right]^{3-}$ to the tris-salicylate $\left[\mathrm{Fe}^{\mathrm{III}}\left(\mathrm{H}_{3} \mathrm{Ent}\right)\right]^{0}$ upon protonation, the coordination chemistry of two new model compounds $N, N^{\prime}, N^{\prime}$-tris[2-(hydroxybenzoyl)carbonyl]cyclotriseryl trilactone (SERSAM) and $N, N^{\prime}, N^{\prime \prime}$-tris[2hydroxy,3-methoxy(benzoyl)carbonyl]cyclotriseryl trilactone (SER(3M)SAM) was examined in solution and solid state. Both SERSAM and SER(3M)SAM form tris-salicylate ferric complexes with spectroscopic and solution thermodynamic properties (with $\log \beta_{110}$ values of 39 and 38 respectively) similar to those of $\left[\mathrm{Fe}^{\mathrm{III}}\left(\mathrm{H}_{3} \mathrm{Ent}\right)\right]^{0}$. The fits of EXAFS spectra of the model ferric complexes and the two forms of ferric enterobactin provided bond distances and disorder factors in the metal coordination sphere for both coordination modes. The protonated $\left[\mathrm{Fe}^{\mathrm{III}}\left(\mathrm{H}_{3} \mathrm{Ent}\right)\right]^{0}$ complex $\left(d_{\mathrm{Fe}-\mathrm{O}}=1.98 \AA, \sigma^{2}\right.$ stat $\left.(\mathrm{O})=0.00351(10) \AA^{2}\right)$ exhibits a shorter average Fe-O bond length but a much higher static Debye-Waller factor for the first oxygen-shell than the catecholate $\left[\mathrm{Fe}^{\mathrm{III}}(\text { Ent })\right]^{3-}$ complex $\left(d_{\mathrm{Fe}-\mathrm{O}}=2.00 \AA, \sigma^{2}{ }_{\text {stat }}(\mathrm{O})=0.00067(14) \AA^{2}\right) .{ }^{1} \mathrm{H}$ NMR spectroscopy was used to monitor the amide bond rotation between the catecholate and salicylate geometries using the gallic complexes of enterobactin; $\left[\mathrm{Ga}^{\mathrm{III}}(\mathrm{Ent})\right]^{3-}$ and $\left[\mathrm{Ga}^{\mathrm{III}}\left(\mathrm{H}_{3} \mathrm{Ent}\right)\right]^{0}$. The ferric salicylate complexes display quasi-reversible reduction potentials from $-89 \mathrm{mV}$ to $-551 \mathrm{mV}$ (relative to the normal hydrogen electrode NHE) which supports the feasibility of a low $\mathrm{pH}$ iron release mechanism facilitated by biological reductants.

\section{Keywords}

Iron Transport; Siderophores; Ferric-Enterobactin; Escherichia coli; Analogs; Coordination Chemistry; Thermodynamic Evaluation; Electrochemistry; Spectroscopy

raymond@ socrates.berkeley.edu.

Supporting Information Available: Figures showing selected spectral data obtained for the spectrophotometric titration of SERSAM and $\left[\mathrm{Fe}^{\mathrm{III}}(\text { SERSAM) }]^{0}\right.$, and the EXAFS characterization of all ferric complexes. Table of EXAFS fit parameters. Selected NOE build-up rates and tables of calculated heats of formation and bond lengths for gallic enterobactin complexes. This material is available free of charge via the Internet at http://pubs.acs.org. 


\section{Introduction}

While enterobactin has been described as an archetype for siderophore mediated iron transport ${ }^{2}$ and much is known about its selective affinity for Fe(III), microbial synthesis and recognition, ${ }^{3,4}$ recent research progress has opened new and surprising aspects of this and related siderophores. Because the growth of pathogenic bacteria depends on adequate iron supply, iron metabolism is a key determinant in bacterial disease.$^{5-9}$ The recent discovery of siderocalin, a protein produced by the human immune system which sequesters and inactivates siderophores, has heightened this significance. ${ }^{10}$ Functionalization to increase siderophore water solubility alters the iron transport capability in a host organism and also the pathogenicity of the producing organism. ${ }^{11,12}$ Many species of Gram-negative enteric bacteria such as Escherichia coli and Salmonella enterica produce and utilize the siderophore enterobactin (Ent) (Figures 1 and 2). ${ }^{2}$ Enterobactin is predisposed for iron binding, with three catecholate units attached to a serine-trilactone scaffold through amide linkages, and exhibits a very high affinity for ferric ion $(\mathrm{pFe}=34.3) .{ }^{13}$ The metabolism of this powerful iron chelator is tightly controlled by the Fur (Fe uptake regulation) protein. ${ }^{7}$ Much is known about the biosynthesis and TolC-dependent exportation of the aposiderophore as well as the TonB-dependent FepA recognition of the enterobactin ferric complex. ${ }^{3,4}$ The iron release mechanism from the ferric enterobactin complex to intracellular iron carriers occurs primarily through enzymatic hydrolysis of the siderophore trilactone backbone by the esterase Fes. ${ }^{14,15}$ However, synthetic analogs of enterobactin, which are not susceptible to this specific hydrolysis, can be $5 \%$ as effective as enterobactin in delivering iron to the cell, and thus sufficient for growth promotion. ${ }^{16,17}$ This result implies the existence of a secondary pathway for intracellular iron release. While ferric enterobactin at neutral $\mathrm{pH}$ cannot release iron by reduction, ${ }^{18,19}$ protonation of ferric enterobactin makes reduction much easier. ${ }^{20}$ Furthermore, low $\mathrm{pH}$ binding of ferric enterobactin raises the question of whether a second type of structure might be recognized by proteins involved in ferric enterobactin metabolism. Studies in progress are investigating this issue.

It has been shown that protonation of ferric enterobactin occurs in three discrete one-proton steps upon acidification, resulting eventually in a triprotonated, neutral ferric complex. ${ }^{21,22}$ Despite thorough literature precedent, ${ }^{21-24}$ confusion about coordination geometry at the metal center has persisted. ${ }^{25}$ Previous studies suggested a structural change for the ferric enterobactin complex from a catecholate to salicylate geometry around the metal ion, where protonation occurs at the meta-hydroxyl oxygen of the catechol, and coordination of $\mathrm{Fe}(\mathrm{III})$ shifts from the two catecholate oxygens to the ortho-hydroxyl oxygen and the amide oxygen (Figure 1). ${ }^{23,24}$ The work presented here confirms the solution and solid state structural alteration of ferric enterobactin upon protonation. Two analogs of enterobactin based on the same serine-trilactone scaffold, SERSAM and SER(3M)SAM, reproduce the salicylate coordination environment of the protonated ferric enterobactin complex (Figure 2). A variety of thermodynamic and spectroscopic measurements (UV-Vis, FTIR, NMR, EXAFS) of the catecholate $\left[\mathrm{Fe}^{\mathrm{III}}(\text { Ent })\right]^{3-},\left[\mathrm{Ga}^{\mathrm{III}}(\text { Ent })\right]^{3-},\left[\mathrm{Fe}^{\mathrm{III}}(\mathrm{TRENCAM})\right]^{3-}$ complexes ${ }^{26}$ and the salicylate analogs $\left[\mathrm{Fe}^{\mathrm{III}}(\mathrm{SERSAM})\right]^{0},\left[\mathrm{Fe}^{\mathrm{III}}(\mathrm{SER}(3 \mathrm{M}) \mathrm{SAM})\right]^{0},\left[\mathrm{Fe}^{\mathrm{III}}(\mathrm{TRENSAM})\right]^{0}$ and $\left[\mathrm{Fe}^{\mathrm{III}}(\mathrm{TREN}(3 \mathrm{M}) \mathrm{SAM})\right]^{0}{ }^{23}$ structurally characterize both coordination modes. Corresponding data as well as DFT calculated structures were obtained for the two protonated $\left[\mathrm{Fe}^{\mathrm{III}}\left(\mathrm{H}_{3} \mathrm{Ent}\right)\right]^{0}$ and $\left[\mathrm{Ga}^{\mathrm{III}}\left(\mathrm{H}_{3} \text { Ent }\right)\right]^{0}$ complexes, establishing their common salicylate geometry. 


\section{Results}

\section{Ligand and Metal Complex Synthesis}

The two new enterobactin analogs SERSAM and SER(3M)SAM were synthesized by using identical methods, as shown in Scheme 1. The serine trilactone (1) was reacted with an excess of either 2-(benzyloxy)benzoyl chloride (2) or 2-(benzyloxy),3-(methoxy)benzoyl chloride (3), and triethylamine in THF. The crude tribenzyl-SERSAM (4) and tribenzylSER(3M)SAM (5) were purified by separation on chromatography columns. Subsequent hydrogenation over $\mathrm{Pd} / \mathrm{C}$ under hydrogen pressure (1 atm) provided pure SERSAM (6) and SER(3M)SAM (7) in good yields. The ligands were both combined with ferric chloride in methanol, with pyridine as a base, to provide the corresponding neutral ferric complexes, $\left[\mathrm{Fe}^{\mathrm{III}}(\mathrm{SERSAM})\right]^{0}$ and $\left[\mathrm{Fe}^{\mathrm{III}}(\mathrm{SER}(3 \mathrm{M}) \mathrm{SAM})\right]^{0}$. Enterobactin (Ent) was also combined with $\mathrm{Fe}(\mathrm{acac})_{3}$ or $\mathrm{Ga}(\mathrm{acac})_{3}$ in methanol to afford the neutral protonated ferric and gallic complexes, $\left[\mathrm{Fe}^{\mathrm{III}}\left(\mathrm{H}_{3} \mathrm{Ent}\right)\right]^{0}$ and $\left[\mathrm{Ga}^{\mathrm{III}}\left(\mathrm{H}_{3} \mathrm{Ent}\right)\right]^{0}$ respectively. Addition of $\mathrm{KOH}$ in the same reaction conditions allowed the isolation of the deprotonated catecholate ferric $\left(\left[\mathrm{Fe}^{\mathrm{III}}(\mathrm{Ent})\right]^{3-}\right)$ and gallic $\left(\left[\mathrm{Ga}^{\mathrm{III}}(\mathrm{Ent})\right]^{3-}\right)$ enterobactin complexes. Electro-spray mass spectrometry (ESMS) showed the molecular peaks of the mononuclear 1:1 ligand to metal complexes for all complexes. No peaks corresponding to complexes having a 2:1 ligand to metal stoichiometries were observed.

\section{FTIR and UV-Vis Spectroscopic Properties}

The solid-state infrared spectral data for SERSAM and SER(3M)SAM exhibit a shift of the carbonyl amide stretching frequencies to lower wave numbers upon complexation with $\mathrm{Fe}^{3+}$ : the carbonyl stretch of the free ligands SERSAM $\left(1641 \mathrm{~cm}^{-1}\right)$ and SER(3M)SAM $\left(1642 \mathrm{~cm}^{-1}\right)$ shift to lower energy by 35 and $38 \mathrm{~cm}^{-1}$ for their corresponding ferric complexes. These observations are in agreement with those reported for similar salicylate complexes and support the assignment of the salicylate mode of coordination. ${ }^{23}$ The metal enterobactin complexes also display characteristic IR frequencies depending on their protonation states, as detailed in a previous study. ${ }^{22}$ Similar infrared spectra are observed for the corresponding ferric or gallic complexes. In aqueous media, $\left[\mathrm{Fe}^{\mathrm{III}}(\mathrm{SERSAM})\right]^{0}$ and $\left[\mathrm{Fe}^{\mathrm{III}}(\mathrm{SER}(3 \mathrm{M}) \mathrm{SAM})\right]^{0}$ both show a strong absorption in the UV due to $\pi-\pi^{*}$ transitions at $304 \mathrm{~nm}\left(\varepsilon=9520 \mathrm{M}^{-1} \mathrm{~cm}^{-1}\right)$ and $312 \mathrm{~nm}\left(\varepsilon=9300 \mathrm{M}^{-1} \mathrm{~cm}^{-1}\right)$, respectively. However, $\left[\mathrm{Fe}^{\mathrm{III}}(\mathrm{SERSAM})\right]^{0}$ exhibits a deep red color resulting from ligand-to-metal-charge-transfer (LMCT) transitions at $\lambda=446 \mathrm{~nm}\left(\varepsilon=3270 \mathrm{M}^{-1} \mathrm{~cm}^{-1}\right)$, which does not correlate well with that of $\left[\mathrm{Fe}^{\mathrm{III}}\left(\mathrm{H}_{3} \mathrm{Ent}\right)\right]^{0}$. The presence of the methoxy groups in the deep purple $\left[\mathrm{Fe}^{\mathrm{III}}(\mathrm{SER}(3 \mathrm{M}) \mathrm{SAM})\right]^{0}\left(\lambda=502 \mathrm{~nm}, \varepsilon=3270 \mathrm{M}^{-1} \mathrm{~cm}^{-1}\right)$ provides a better spectroscopic model for $\left[\mathrm{Fe}^{\mathrm{III}}\left(\mathrm{H}_{3} \mathrm{Ent}\right)\right]^{0.13}$

\section{Ligand Protonation Constants and Stability of Ferric Salicylate complexes}

The stepwise proton association constants as defined by equations 1,2, and 3 and the ferric complex formation constant (eq. 4) were determined by spectrophotometric titrations for the two new salicylate ligands. Due to limited solubility in water, SERSAM and SER(3M)SAM were titrated at low concentration by monitoring the spectral changes as a function of $\mathrm{pH}$ throughout the $\mathrm{pH}$ range of 4.5 to 10.0. The compounds were titrated only from low to high $\mathrm{pH}$ to avoid base-catalyzed hydrolysis of the backbone. ${ }^{19}$ In both cases, the intense UV absorption band of the salicylate functionality increases in intensity and shifts to longer wavelengths as the $\mathrm{pH}$ is increased to 10 (Figures 3 and S1). Factor analysis ${ }^{27}$ of the titration curves (each data set comprising about 60 spectra and 151 wavelengths for each replicate) indicated for each ligand three sequential protonation equilibria corresponding to $\log K_{a}$ values reported in Table 1 . The best nonlinear least squares refinements were obtained with the models including four species: $\mathrm{L}^{3-}, \mathrm{LH}^{2-}, \mathrm{LH}_{2}^{-}$, and $\mathrm{LH}_{3}$. The refined constants are 
comparable to the values previously reported for the stepwise protonation of the tripodal TREN-based analogs TRENSAM and TREN(3M)SAM. ${ }^{23}$

$$
\begin{gathered}
\mathrm{H}_{n-1} \mathrm{~L}+\mathrm{H}^{+} \leftrightarrow \mathrm{H}_{n} \mathrm{~L} \quad K_{01 \mathrm{n}}=\frac{\left[\mathrm{H}_{n} \mathrm{~L}\right]}{\left[\mathrm{H}_{n-1} \mathrm{~L}|| \mathrm{H}^{+}\right]} \\
\mathrm{L}+h \mathrm{H}^{+} \leftrightarrow \mathrm{H}_{h} \mathrm{~L} \quad \beta_{\text {olh }}=\frac{\left[\mathrm{H}_{h} \mathrm{~L}\right]}{\left[\mathrm{L}|| \mathrm{H}^{+}\right]^{h}} \\
K_{0 l n}=\frac{\left[\mathrm{H}_{n} \mathrm{~L}\right]}{\left[\mathrm{H}_{n-1} \mathrm{~L}\right]\left[\mathrm{H}^{+}\right]}=\frac{\beta_{0 \mid n}}{\beta_{0 l(n-1)}} \\
m \mathrm{M}+l \mathrm{~L}+h \mathrm{H}^{+} \leftrightarrow \mathrm{M}_{m} \mathrm{~L}_{l} \mathrm{H}_{h} \quad \beta_{m l h}=\frac{\left[\mathrm{M}_{m} \mathrm{~L}_{l} \mathrm{H}_{h}\right]}{\mid \mathrm{M}]^{m}[\mathrm{~L}]^{l}\left[\mathrm{H}^{+}\right]^{h}}
\end{gathered}
$$

Spectrophotometric titrations, monitoring wavelengths between 250 and $700 \mathrm{~nm}$, were also performed for ferric SERSAM and ferric SER(3M)SAM from pH 5.5 to 2 and are shown in Figures 3 and S1. Increasing the $\mathrm{pH}$ above 7 resulted in the complete disappearance of the charge-transfer band due to formation of iron hydroxide. The complexes are stable only in neutral to acidic conditions. As the $\mathrm{pH}$ is lowered, the intensity of the LMCT band decreases and finally vanishes around $\mathrm{pH}=2$. At low $\mathrm{pH}$, the intense $\pi-\pi^{*}$ transitions resolve as a narrower band $\left(\lambda=300 \mathrm{~nm}, \varepsilon=5025 \mathrm{M}^{-1} \mathrm{~cm}^{-1}\right.$ and $\lambda=314 \mathrm{~nm}, \varepsilon=7018 \mathrm{M}^{-1} \mathrm{~cm}^{-1}$ for SERSAM and SER(3M)SAM, respectively), the final spectrum being identical to the spectrum calculated for $\mathrm{LH}_{3}$ species. The nonlinear least-squares refinements ${ }^{27}$ of the overall formation constants $\beta_{110}$ included in each case the three protonation constants derived from spectrophotometric titrations (Table 1 ) and the metal hydrolysis products, whose equilibrium constants were fixed to the literature values ${ }^{28}\left(\log \beta_{10-1}=-2.61, \log \right.$ $\beta_{10-2}=-5.66, \log \beta_{20-2}=2.86$ ) and which do not absorb significantly.

\section{DFT Calculations on Catecholate and Salicylate Enterobactin Metal Complexes}

The relative conformational stability of the two most probable binding modes of protonated ferric enterobactin $\left[\mathrm{Fe}^{\mathrm{III}}\left(\mathrm{H}_{3} \mathrm{Ent}\right)\right]^{0}$ was investigated by molecular modeling. Density functional theory calculations ${ }^{29}$ were performed on the ferric and gallic complexes $\left[\mathrm{Fe}^{\mathrm{III}}(\mathrm{Ent})\right]^{3-},\left[\mathrm{Ga}^{\mathrm{III}}(\mathrm{Ent})\right]^{3-}$, cat-[Fe $\left.\mathrm{Fe}^{\mathrm{III}}\left(\mathrm{H}_{3} \mathrm{Ent}\right)\right]^{0}$, cat- $\left[\mathrm{Ga}^{\mathrm{III}}\left(\mathrm{H}_{3} \mathrm{Ent}\right)\right]^{0}$, sal- $\left[\mathrm{Fe}^{\mathrm{III}}\left(\mathrm{H}_{3} \mathrm{Ent}\right)\right]^{0}$, and sal-[Ga $\left.\mathrm{Ga}_{(\mathrm{II}}\left(\mathrm{H}_{3} \mathrm{Ent}\right)\right]^{0}$ where the prefixes "cat" and "sal" designate the catecholate and salicylate possible binding modes. The geometry of each complex was optimized with Jaguar at the b3lyp / lacvp** level. The complete d-shell of Ga ${ }^{\mathrm{III}}$ provides complexes with a lower spin-state than that of the equivalent ferric complexes, which facilitates the convergence of the calculation. In the $\mathrm{Fe}^{\mathrm{III}}$ case, iguess $=10$ and iacscf $=2$ values were added to the default parameters to satisfy the SCF convergence criteria. Frequency calculations, which were performed on all structures, verified that the optimized geometries were minima (no negative frequencies) on the potential energy surface. For both metals, the same trends were observed. The results indicate that the protonated salicylate binding mode is energetically favored over the protonated catecholate mode with a heat of formation difference of $10 \mathrm{kcal}^{\mathrm{mol}}{ }^{-1}\left(24 \mathrm{kcal} . \mathrm{mol}^{-1}\right)$ in the ferric (gallic respectively) complexes; geometric parameters and relative energies are summarized in Tables 2, S2 and S3. As expected, ${ }^{30}$ the calculated $\mathrm{M}-\mathrm{O}$ bond lengths for $\left[\mathrm{Ga}^{\mathrm{III}}(\mathrm{Ent})\right]^{3-}$ are substantially shorter than for $\left[\mathrm{Fe}^{\mathrm{III}}(\mathrm{Ent})\right]^{3-}$. In both cases, the distances between the catechol oxygen atoms and the 
metal ion are unequivalent. The distance between metal and the ortho catechol oxygen atom $\mathrm{O}_{\text {ortho }}$ is longer than the corresponding distance of the meta catechol oxygen atom $\mathrm{O}_{\text {meta }}$, which is consistent with the parameters obtained from the $\left[\mathrm{V}^{\mathrm{IV}}(\mathrm{Ent})\right]^{2-} \mathrm{X}$-ray structure. ${ }^{31}$ The M-O bond lengths of the protonated models also vary significantly from the deprotonated catecholate model; the average $\mathrm{M}-\mathrm{O}$ bond distance is shorter for the salicylate (and longer for the catecholate respectively) protonated complex $\left[\mathrm{M}^{\mathrm{III}}\left(\mathrm{H}_{3} \mathrm{Ent}\right)\right]^{0}$ than for $\left[\mathrm{M}^{\mathrm{III}}(\text { Ent) }]^{3-}\right.$. The assignment of the frontier orbitals, for both $\left[\mathrm{Fe}^{\mathrm{III}}(\mathrm{Ent})\right]^{3-}$ and sal$\left[\mathrm{Fe}^{\mathrm{III}}\left(\mathrm{H}_{3} \text { Ent) }\right]^{0}\right.$, are consistent with $\mathrm{D}_{3}$ symmetric high-spin $\mathrm{d}^{5}$ iron complexes (Figure 4), with d-orbital energy levels that are significantly lower for sal-[ $\left[\mathrm{Fe}^{\mathrm{III}}\left(\mathrm{H}_{3} \mathrm{Ent}\right)\right]^{0}$ than for $\left[\mathrm{Fe}^{\mathrm{III}}(\mathrm{Ent})\right]^{3-}$. It has been shown previously that the broad LMCT band in the absorption spectra of ferric tris-catecholate complexes is composed of two overlapping, $x, y$ polarized, one-electron transitions: $\mathrm{a}_{2} \rightarrow \mathrm{e}^{\mathrm{a}}$ and $\mathrm{e}_{\pi 1} \rightarrow \mathrm{e}^{\mathrm{a}} .{ }^{32}$ The calculated energy difference between the $\mathrm{e}^{\mathrm{a}}$ orbitals of sal-[Fe $\left.\mathrm{Fe}^{\mathrm{III}}\left(\mathrm{H}_{3} \mathrm{Ent}\right)\right]^{0}$ and $\left[\mathrm{Fe}^{\mathrm{III}}(\mathrm{Ent})\right]^{3-}$ is $\Delta E_{e} a=9.3 \mathrm{eV}$. This corresponds to $\Delta_{e} a=141 \mathrm{~nm}$, causing the color change from deep red to violet upon protonation of ferric enterobactin. ${ }^{13}$ Lastly, the LUMO orbital of the sal- $\left[\mathrm{Fe}^{\mathrm{III}}\left(\mathrm{H}_{3} \mathrm{Ent}\right)\right]^{0}$ model is primarily from the ligand's electron density in proximity of the coordination sphere, and is $8.1 \mathrm{eV}$ lower in energy as compared to the LUMO of $\left[\mathrm{Fe}^{\mathrm{IIII}}(\mathrm{Ent})\right]^{3-}$, which displays electron density only in the trilactone region.

\section{EXAFS Spectroscopic Analysis}

Samples of protonated $\left[\mathrm{Fe}^{\mathrm{III}}\left(\mathrm{H}_{3} \mathrm{Ent}\right)\right]^{0}$ and deprotonated $\left[\mathrm{Fe}^{\mathrm{III}}(\mathrm{Ent})\right]^{3-}$ as well as the salicylate ferric complexes $\left[\mathrm{Fe}^{\mathrm{III}}(\mathrm{SERSAM})\right]^{0}$ and $\left[\mathrm{Fe}^{\mathrm{III}}(\mathrm{SER}(3 \mathrm{M}) \mathrm{SAM})\right]^{0}$, were subjected to temperature-dependent (30, 100, 200 and $300 \mathrm{~K}) \mathrm{Fe}$ K-edge extended X-ray absorption fine structure measurements. The ferric complexes of TRENSAM, TREN(3M)SAM, and TRENCAM (Figure 2) were used as model compounds for the salicylate and catecholate binding modes respectively. ${ }^{23,26}$ The XANES spectra of the compounds were identical, as expected from the similar coordination environments of the ferric ion in all complexes. Differences in the EXAFS spectra were expected to be small since there is only a slight change in bond distance between the iron - catechol oxygen and the iron - amide oxygen $(0.03-0.13 \AA)$. In fact, in all complexes this distance is below the resolution limit of EXAFS $(1 / \Delta \mathrm{k})$, where $\Delta \mathrm{k}$ is the usable data $\mathrm{k}$-range. The temperature-dependent EXAFS data however allow the determination of static Debye-Waller factors, which show differences in the positional disorder of the catechol and amide oxygens, and are representative of the catecholate and salicylate coordinations. EXAFS fits were extended to the second carbon shell of the ferric complexes. Though good quality data extended to at least $\mathrm{k}=12.0 \AA^{-1}$ in all cases, a limited $\mathrm{k}$ range was Fourier transformed $\left(2.5-9.0 \AA^{-1}\right)$ because of temperature-dependent changes in the spectra occurring in the region of $10 \AA^{-1}$. These changes did not seem to affect the fits for the first two shells and cannot be attributed to spin-crossover effects ${ }^{33}$ since Mössbauer and EPR experiments have confirmed the highspin state of the ferric enterobactin and analogs complexes from $4 \mathrm{~K}$ to RT. ${ }^{34,35}$ Due to the short $\mathrm{k}$ range employed, there were only a few degrees of freedom available (11 in most cases) for varying the fitting parameters. The analysis focused on fitting the first two shells and relied on parameters obtained from crystal structures of the ferric complexes of the

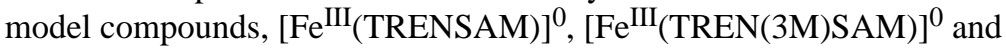
$\left[\mathrm{Fe}^{\mathrm{III}}(\mathrm{TRENCAM})\right]^{3-23,26}$ The final parameters were determined based on low residuals and robustness of the fits. Special attention was paid to parameter correlation, specifically $\left(E_{0}, R, \mathrm{C}_{3}\right)$ and $\left(\mathrm{A}, \sigma^{2}, \mathrm{CN}\right)$ which are highly correlated among each other. In general, these correlations were avoided by fixing parameter values iteratively and using values established from the model compounds. In the same manner, the robustness of each parameter was established. The best EXAFS fits for the three model compounds were obtained at $200 \mathrm{~K}$ and the experimental parameters were in very good agreement with those determined by Xray diffraction at $172 \mathrm{~K} .{ }^{23,26}$ Multiple temperature data were fit using an Einstein model, 
which considers the pair of absorber and back-scatterer atoms as an independent oscillator with frequency $\omega_{E}$, and is particularly suited for monitoring intramolecular vibrational modes. ${ }^{36,37}$ For atoms positioned further than $3 \AA$ away from the iron center, the competition between noise and back/multiple scattering contributions becomes nonnegligible, ${ }^{38}$ therefore only the first oxygen-coordination shell and the second carboncoordination shell were studied. Analysis of the temperature dependence of the mean-square relative displacement (MSRD) allowed the determination of the static Debye-Waller $\left(\sigma_{\text {stat }}^{2}\right)$ component, by elimination of the temperature dependent thermal disorder Debye-Waller component $\left(\sigma_{\text {vib }}^{2}\right)\left(\right.$ eq 5). ${ }^{39}$

$$
\sigma_{v i b}^{2}(T)=\frac{\hbar^{2}}{2 \Theta_{E} k_{B} \mu} \operatorname{coth}\left(\frac{\Theta_{E}}{2 T}\right), \Theta_{E}=\frac{\hbar \omega_{E}}{k_{B}}
$$

The Einstein characteristic temperature $\Theta_{E}$ was established for each compound, indicative of the overall Debye-Waller factor for the shell as a function of temperature, and of the effective bond-stretching force constant. The k-space and r-space spectra are shown in Figures 5 and S2-4. Results of fits to the data are summarized in Table 3. The temperature averaged distances between the iron center and the first-shell oxygens and the second-shell carbons display consistent trends for catecholate $v s$ salicylate coordination. The salicylate $\left[\mathrm{Fe}^{\mathrm{III}}(\mathrm{SERSAM})\right]^{0},\left[\mathrm{Fe}^{\mathrm{III}}(\mathrm{SER}(3 \mathrm{M}) \mathrm{SAM})\right]^{0},\left[\mathrm{Fe}^{\mathrm{III}}(\mathrm{TRENSAM})\right]^{0}$ and $\left[\mathrm{Fe}^{\mathrm{III}}(\mathrm{TREN}(3 \mathrm{M}) \mathrm{SAM})\right]^{0}$ complexes have shorter $\mathrm{Fe}-\mathrm{O}$ bond distances and longer Fe-C distances than their respective catecholate analogs $\left[\mathrm{Fe}^{\mathrm{III}}(\mathrm{Ent})\right]^{3-}$ and $\left[\mathrm{Fe}^{\mathrm{III}}(\mathrm{TRENCAM})\right]^{3-}$. The triprotonated species $\left[\mathrm{Fe}^{\mathrm{III}}\left(\mathrm{H}_{3} \mathrm{Ent}\right)\right]^{0}$ also exhibits shorter $\mathrm{Fe}-\mathrm{O}$ and longer $\mathrm{Fe}-\mathrm{C}$ bonds than $\left[\mathrm{Fe}^{\mathrm{III}}(\mathrm{Ent})\right]^{3-}$, consistent with conversion to salicylate coordination. The static Debye-

Waller factor $\left(\sigma_{\text {stat }}^{2}\right)$ was determined from Einstein model fits to the temperature-dependent EXAFS data (Figure 6). The salicylate compounds $\left[\mathrm{Fe}^{\mathrm{III}}(\text { SERSAM) }]^{0}\right.$, $\left[\mathrm{Fe}^{\mathrm{III}}(\mathrm{SER}(3 \mathrm{M}) \mathrm{SAM})\right]^{0}$, [Fe $\left.^{\mathrm{III}}(\mathrm{TRENSAM})\right]^{0}$ and $\left[\mathrm{Fe}^{\mathrm{III}}(\mathrm{TREN}(3 \mathrm{M}) \mathrm{SAM})\right]^{0}$ show a similar pattern in that the oxygen $\sigma_{\text {stat }}^{2}$ values (and to a lesser extent the carbon $\sigma_{\text {stat }}^{2}$ values) are much larger than those observed for the catecholate compounds $\left[\mathrm{Fe}^{\mathrm{III}}(\text { Ent })\right]^{3-}$ and $\left[\mathrm{Fe}^{\mathrm{III}}(\mathrm{TRENCAM})\right]^{3-}$, indicating a larger positional disorder in these shells. In the same manner, the $\sigma_{\text {stat }}^{2}$ values are larger for $\left[\mathrm{Fe}^{\mathrm{III}}\left(\mathrm{H}_{3} \mathrm{Ent}\right)\right]^{0}$ than for $\left[\mathrm{Fe}^{\mathrm{III}}(\mathrm{Ent})\right]^{3-}$. Furthermore, the Einstein characteristic temperatures $\Theta_{E}$ are greater for the oxygen shell than for the carbon shell for all salicylate compounds whereas the opposite trend is seen for the catecholate compounds.

\section{Structural Characterization of Gallic Enterobactin by NMR}

Previous spectroscopic studies have shown that the gallium complex of enterobactin exhibits the same behavior upon acidification as ferric enterobactin. ${ }^{13}$ To provide more information on the coordination shift, the protonation steps of this diamagnetic complex were followed by ${ }^{1} \mathrm{H}$ NMR. The ${ }^{1} \mathrm{H}$ NMR titration was conducted from $\mathrm{pD}=9.6$ to 2.4 in $\mathrm{D}_{2} \mathrm{O}$. Acidification of the complex resulted in drastic changes in the chemical shifts of the various protons (Figure 7). Least square refinements of the chemical shifts variation produced similar $\mathrm{p} K_{a}$ values to those obtained spectrophotometrically $\left(\mathrm{p} K_{a 1}=5.05(1), \mathrm{p} K_{a 2}=4.19(1)\right.$, $\left.\mathrm{p} K_{a 3}=2.93(1)\right) .{ }^{13}$ More importantly, the coordination shift happens during the third protonation of the complex. Indeed, a major upfield shift followed by an inflection point at $\mathrm{pD} \sim 3.3$ is observed for the protons $\mathrm{H}_{\mathrm{a}}$ and $\mathrm{H}_{\mathrm{c}}$ in the proximity of the amide carbonyl oxygens, at low pD values (below the second $\mathrm{p} K_{a}$ ). As determined with DFT calculations, both of these sets of protons should point toward the periphery of the molecule, in the same direction as the carbonyl oxygens in the case of $\left[\mathrm{Ga}^{\mathrm{III}}(\mathrm{Ent})\right]^{3-}$ and opposite that direction for $\left[\mathrm{Ga}^{\mathrm{III}}\left(\mathrm{H}_{3} \mathrm{Ent}\right)\right]^{0}$, and should be sensitive to a rotation of the amide bond. Precipitation of the 
protonated gallic enterobactin occured when the $\mathrm{pD}$ value reached 2.4. The precipitate was filtered, rinsed with water, dried and dissolved in DMSO- $d_{6}$ to be identified as the complex $\left[\mathrm{Ga}^{\mathrm{III}}\left(\mathrm{H}_{3} \mathrm{Ent}\right)\right]^{0}$, using ${ }^{1} \mathrm{H}$ and ${ }^{13} \mathrm{C}$ NMR. The ${ }^{13} \mathrm{C}$ NMR chemical shifts in DMSO- $d_{6}$ are also indicative of a salicylate shift. Indeed, as the catecholate complex $\left[\mathrm{Ga}^{\mathrm{III}}(\mathrm{Ent})\right]^{3-}$ is protonated to $\left[\mathrm{Ga}^{\mathrm{III}}\left(\mathrm{H}_{3} \mathrm{Ent}\right)\right]^{0}$, the amide carbonyl peak is shifted down field from 168.7 ppm to $180.1 \mathrm{ppm}$ whereas the benzoyl meta-carbon peak displays an upfield shift of 9.1 ppm. ${ }^{40}$ Furthermore, 2D-gradient NOESY experiments were performed in DMSO- $d_{6}$ on the two gallic complexes $\left[\mathrm{Ga}^{\mathrm{III}}(\text { Ent) }]^{3-}\right.$ and $\left[\mathrm{Ga}^{\mathrm{III}}\left(\mathrm{H}_{3} \mathrm{Ent}\right)\right]^{0}$ (Figure 8 ). Spectra were collected at a variety of mixing times ( $\tau_{m}$ from $0.15 \mathrm{~s}$ to $1 \mathrm{~s}$ ) to observe the growth of the NOE signals. The rate of the NOE cross peak intensity growth is inversely proportional to the sixth power of the distance between nuclei (Figure S5). ${ }^{41}$ As suggested by the DFT calculated structures, the amide bond rotates upon acidification, which causes the intensities of the cross peaks between the amide proton and the benzoyl ortho-proton or one of the seryl $\beta$-proton to increase significantly. These correlations are highlighted in Figure 8.

\section{Electrochemical Characterization of Ferric Salicylate Complexes}

Due to the low solubility of these neutral complexes in water, the cyclic voltammograms of the salicylate analogs of ferric enterobactin were recorded in acetonitrile using ferrocene as a standard (Figure 9). Quasireversible signals centered at $-991,-919,-797$ and $-529 \mathrm{mV} /$ $0.01 \mathrm{M} \mathrm{AgNO}_{3}$ were found for the iron complexes of TRENSAM, TREN(3M)SAM, SERSAM and SER(3M)SAM, respectively. In all cases, the peak separation between the cathodic and the anodic waves is independent of the sweep rate in the range 50-200 mV/s, and the peak current $I_{\text {red }}$ is a linear function of the square root of the sweep rate, indicating diffusion limited reduction processes (Figure 9). The half-wave potential $v s$ NHE in water can be estimated by Equation 6;42 $E_{\mathrm{NHE}}^{1 / 2}\left(\mathrm{H}_{2} \mathrm{O}\right), E_{\mathrm{Ag}^{+} / \mathrm{Ag}}^{1 / 2}(\mathrm{~S}), \Delta \mathrm{G}_{\mathrm{tr}}$, and $a_{\mathrm{Ag}^{+}}$stand for the estimated reduction potential ( $v s \mathrm{NHE}$ ) in water, the measured reduction potential $v s$ the Pleskow electrode in the organic solvent, the free energy change of transfer of $\mathrm{Ag}^{+}$from water to the organic solvent, and $\mathrm{Ag}^{+}$ion activity in the reference compartment, respectively. The $\Delta \mathrm{G}_{\text {tr }}$ values ( $-23.2 \mathrm{~kJ} \mathrm{~mol}^{-1}$ for acetonitrile) have been tabulated by IUPAC. ${ }^{43}$

$E_{\mathrm{NHE}}^{1 / 2}\left(\mathrm{H}_{2} \mathrm{O}\right)=E_{\mathrm{Ag}^{+} / \mathrm{Ag}}^{1 / 2}(\mathrm{~S})+E_{\mathrm{NHE}}^{0}\left(\mathrm{Ag}^{+}, \mathrm{H}_{2} \mathrm{O}\right)-\left\{\Delta G_{\mathrm{tr}}+R T \ln a_{\mathrm{Ag}^{+}}\right\} / n F=E_{\mathrm{Ag}^{+} / \mathrm{Ag}}^{1 / 2}(\mathrm{~S})+440 \mathrm{mV}$

The reduction potentials for the ferric complexes [Fe $\left.{ }^{\mathrm{III}}(\mathrm{TRENSAM})\right]^{0}$, $\left.\left[\mathrm{Fe}^{\mathrm{III}}(\mathrm{TREN}(3 \mathrm{M}) \mathrm{SAM})\right]^{0}, \mathrm{Fe}^{\mathrm{III}}(\mathrm{SERSAM})\right]^{0}$ and $\left[\mathrm{Fe}^{\mathrm{III}}(\mathrm{SER}(3 \mathrm{M}) \mathrm{SAM})\right]^{0}$ were calculated using Equation 6 and are reported in Table 4. These experimental values are much higher than those observed for the corresponding catecholate siderophore complexes $\left[\mathrm{Fe}^{\mathrm{III}}(\mathrm{TRENCAM})\right]^{3-}$ and $\left[\mathrm{Fe}^{\mathrm{III}}(\mathrm{Ent})\right]^{3-} .{ }^{44}$ The ligands built on a serine-trilactone scaffold form ferric complexes with higher reduction potentials than the equivalent TREN-based compounds. This trend has been observed earlier with hydroxypyridonate enterobactinanalogs. ${ }^{45}$

\section{Discussion}

\section{Salicylate Ferric Complexes as Model Compounds}

What is the structure of protonated ferric enterobactin and how might the change in structure alter recognition and function? The SERSAM and SER(3M)SAM ligand systems were designed to explore the structural and spectroscopic features of a tris-salicylate ligand built around the enterobactin triserine-backbone. A previous study had demonstrated the validity of the salicylate coordination with the TREN-based analogs TRENSAM and 
TREN(3M)SAM bound to hard metal cations such as $\mathrm{Fe}^{3+}$ and $\mathrm{Al}^{3+}{ }^{23}$ As anticipated, the IR and UV-Vis spectra of the $\left[\mathrm{Fe}^{\mathrm{III}}(\mathrm{SERSAM})\right]^{0}$ and $\left[\mathrm{Fe}^{\mathrm{III}}(\mathrm{SER}(3 \mathrm{M}) \mathrm{SAM})\right]^{0}$ complexes exhibited similar features to those of $\left[\mathrm{Fe}^{\mathrm{III}}(\mathrm{TRENSAM})\right]^{0}$ and $\left[\mathrm{Fe}^{\mathrm{III}}(\mathrm{TREN}(3 \mathrm{M}) \mathrm{SAM})\right]^{0}$ respectively, ${ }^{23}$ which corroborates the formation of tris-salicylato complexes. In addition, the 3-methoxy substituted [Fe $\left.{ }^{I I I}(\mathrm{SER}(3 \mathrm{M}) \mathrm{SAM})\right]^{0}$ proves to be the best spectroscopic model for the protonated $\left[\mathrm{Fe}^{\mathrm{III}}\left(\mathrm{H}_{3} \mathrm{Ent}\right)\right]^{0}$ complex, as emphasized by the nearly identical UV spectra of the two species. The formation constants determined for both new salicylate ferric complexes $\left[\mathrm{Fe}^{\mathrm{III}}(\mathrm{SERSAM})\right]^{0}$ and $\left[\mathrm{Fe}^{\mathrm{III}}(\mathrm{SER}(3 \mathrm{M}) \mathrm{SAM})\right]^{0}$ correlate very well with the calculated hypothetical formation constant of the triprotonated $\left[\mathrm{Fe}^{\mathrm{III}}\left(\mathrm{H}_{3} \mathrm{Ent}\right)\right]^{0}$, as shown by the equations depicted in Table 5, and therefore confirm that the salicylate coordination mode is an excellent model for $\left[\mathrm{Fe}^{\mathrm{III}}\left(\mathrm{H}_{3} \mathrm{Ent}\right)\right]^{0} .{ }^{13,21}$

\section{Structural Studies of the Catecholate and Salicylate Coordinations}

The density functional theory calculations conducted on ferric and gallic enterobactin complexes in the deprotonated and fully protonated states imply that these closely related metal cations are subject to the same type of coordination in similar conditions. In both cases, the salicylate binding mode was found to be substantially lower in energy than the catecholate coordination for triprotonated complexes. The calculated d-orbital energy levels were consistent with the LMCT energy shift observed in the absorption spectra of $\left[\mathrm{Fe}^{\mathrm{III}}(\mathrm{Ent})\right]^{3-}$ and its protonated form. ${ }^{13}$ Moreover, as established by the EXAFS and NMR analyses of the respective ferric and gallic complexes, the average metal-oxygen bond lengths shorten upon protonation; this trend is consistent with the calculated parameters of the protonated salicylate models as opposed to the elongation of bonds found for the protonated catecholate models. The EXAFS experimental results showed a higher $\sigma_{\text {stat }}^{2}$ parameter value for salicylate complexes than for the corresponding catecholate ones, describing an environment with a higher static disorder in the first coordination shell of oxygen around the metal center. Indeed, for the salicylate-bound compounds, the coordinating oxygen atoms are no longer all phenolate oxygens, three of them are carbonyl oxygens. Another set of key parameters is noticeably different in both coordination modes: in the catecholate coordination, the Einstein characteristic temperature $\Theta_{E}$ is greater for the carbon shell than for the oxygen shell, as opposed to the salicylate binding mode. The metaloxygen bond strengths are comparable for both coordination modes while the deformation vectors corresponding to the metal-carbon shell have a larger contribution in the salicylate geometry. This causes the metal-carbon force constants to be weaker in the salicylate case and therefore affects the relative value of the carbon shell Einstein temperature. NMR characterization of the gallic complexes of enterobactin also confirmed the hypothesis of a switch to salicylate coordination upon protonation. Acidification of the catecholate $\left[\mathrm{Ga}^{\mathrm{III}}(\mathrm{Ent})\right]^{3-}$ complex results in rotation of the amide bonds to permit binding of the metal ion to the carbonyl oxygens. The ${ }^{1} \mathrm{H}$ and ${ }^{13} \mathrm{C}$ magnetic resonance peaks are therefore shifted down or up field depending on the proximity of the nuclei to the gallium center. The intensities of the NOE cross peaks for each complex provide relative measurements of the distances between the nuclei, and show that the amide protons approach the benzoyl orthoproton as well as the seryl $\beta$-proton as the change from catecholate to salicylate coordination occurs.

\section{Reduction Potentials of Ferric-Salicylate Complexes}

A secondary mechanism for iron release by enterobactin relies on the hypothesis that protonation of ferric enterobactin increases its reduction significantly. ${ }^{18,19}$ The reduction potentials of the salicylate analogs of ferric enterobactin (Table 4) are well within the range of biological reductants and much higher than those typically observed for the corresponding catecholate siderophores. Noteworthy, the reduction potentials observed for the hydroxamate siderophores ferrichrome A and ferrioxamine B are in the same range 
(Table 4). ${ }^{18}$ The triserine trilactone stabilizes the ferrous over the ferric state compared with the TREN scaffold ${ }^{45}$ this trend is also seen in the salicylate compounds, since the reduction potentials of $\left[\mathrm{Fe}^{\mathrm{III}}(\mathrm{SERSAM})\right]^{0}$ and $\left[\mathrm{Fe}^{\mathrm{III}}(\mathrm{SER}(3 \mathrm{M}) \mathrm{SAM})\right]^{0}$ are higher than those of $\left[\mathrm{Fe}^{\mathrm{III}}(\mathrm{TRENSAM})\right]^{0}$ and $\left[\mathrm{Fe}^{\mathrm{III}}(\mathrm{TREN}(3 \mathrm{M}) \mathrm{SAM})\right]^{0}$.

\section{Conclusion}

Enterobactin is inactivated in human serum by non-specific binding to human serum albumin and is bound by the human immune protein siderocalin more strongly than by FepA, the bacterial receptor for the siderophore. ${ }^{7,10}$ Recent studies have shown that enzymatic functionalization of enterobactin makes water soluble derivatives that evade these traps. ${ }^{11,12}$ At low $\mathrm{pH}$ ferric enterobactin is protonated, remains intact and undergoes a marked structural change. The EXAFS and NMR structural studies reported here show that ferric enterobactin goes through a change from the catecholate coordination of $\left[\mathrm{Fe}^{\mathrm{III}}(\mathrm{Ent})\right]^{3-}$ to a salicylate mode of binding for $\left[\mathrm{Fe}^{\mathrm{III}}\left(\mathrm{H}_{3} \mathrm{Ent}\right)\right]^{0}$ upon protonation. The new synthetic hexadentate trilactone-based analogs SERSAM and SER(3M)SAM form tris-salicylate ferric complexes as do the previously made TRENSAM and TREN(3M)SAM chelators. These salicylate analogs of enterobactin are excellent spectroscopic and thermodynamic models for the tri-protonated $\left[\mathrm{Fe}^{\mathrm{III}}\left(\mathrm{H}_{3} \mathrm{Ent}\right)\right]^{0}$ complex. In addition, they exhibit reduction potentials high enough to be in the range of biological reductants. Protonation of ferric enterobactin generates a large change in coordination mode and a corresponding overall alteration in molecular shape and charge, as well as a weakened iron binding affinity.

\section{Experimental Section}

\section{Synthesis}

General-All chemicals were obtained from commercial suppliers and were used as received. The starting materials tris $\left(N\right.$-hydrochloride-L-serine) trilactone $^{45}(\mathbf{1}), 2$ (benzyloxy)benzoyl chloride ${ }^{23,24}$ (2), 2-(benzyloxy),3-(methoxy)benzoyl chloride ${ }^{23,24}$ (3), as well as the ligand enterobactin ${ }^{31}$ and the ferric complexes [Fe ${ }^{\mathrm{III}}$ (TRENCAM) $]^{3-},{ }^{26}$ $\left[\mathrm{Fe}^{\mathrm{III}}(\mathrm{TRENSAM})\right]^{0},{ }^{23}$ and $\left[\mathrm{Fe}^{\mathrm{III}}(\mathrm{TREN}(3 \mathrm{M}) \mathrm{SAM})\right]^{0}$ were prepared according to procedures described in the designated references. Flash silica gel chromatography was performed using Merck 40-70 mesh silica gel. Melting points were taken on a Büchi melting apparatus and are uncorrected. All NMR spectra were recorded at ambient temperature on Bruker FT-NMR spectrometers at the NMR Laboratory, University of California, Berkeley. Microanalyses were performed by the Microanalytical Services Laboratory, College of Chemistry, University of California, Berkeley. Mass spectra were recorded at the Mass Spectrometry Laboratory, College of Chemistry, University of California, Berkeley. Infrared spectra were measured using a Thermo Nicolet IR Avatar 370 Fourier transform spectrometer. UV-Visible absorption spectra were taken on a Varian Cary $300 \mathrm{UV}-\mathrm{Vis}$ spectrometer.

\section{$N, N$, $N$ '-Tris[2-(benzyloxybenzoyl)carbonyl]cyclotriseryl trilactone, tribenzyl-SERSAM (4)}

Tris( $N$-hydrochloride-L-serine) trilactone $(0.371 \mathrm{~g}, 1.0 \mathrm{mmol})$ was suspended in $40 \mathrm{~mL}$ of dry and degassed THF and cooled in an ice/water bath. Solutions of 2-(benzyloxy)benzoyl chloride $(1.23 \mathrm{~g}, 5.0 \mathrm{mmol})$ in $10 \mathrm{~mL}$ of THF and triethylamine $(1.01 \mathrm{~g}, 10 \mathrm{mmol})$ were added simultaneously dropwise via syringes over 10 minutes into this suspension while stirring under nitrogen. The mixture was allowed to warm to room temperature and stirred over night. It was then filtered, concentrated, applied to a silica gel column and eluted with 96:4 $\mathrm{CH}_{2} \mathrm{Cl}_{2}: \mathrm{MeOH}$. Fractions were combined and evaporated to a white solid. Yield: 0.28 g (30\%). ${ }^{1} \mathrm{H}$ NMR (400 MHz, $\left.\mathrm{CDCl}_{3}\right): \delta 4.20(\mathrm{dd}, J=6.8 \mathrm{~Hz}, J$ ' $=4.4 \mathrm{~Hz}, 3 \mathrm{H}), 4.37(\mathrm{dd}, J$ $\left.=4.4 \mathrm{~Hz}, J^{\prime}=6.4 \mathrm{~Hz}, 3 \mathrm{H}\right), 5.00-5.11(\mathrm{~m}, 9 \mathrm{H}), 6.90-7.58(\mathrm{~m}, 24 \mathrm{H}), 8.15(\mathrm{~d}, J=1.6 \mathrm{~Hz}, 3 \mathrm{H})$, 
$8.54(\mathrm{~d}, J=6.8 \mathrm{~Hz}, 3 \mathrm{H}) \mathrm{ppm}$. (+)-FABMS: m/z $892.6\left(\mathrm{MH}^{+}\right)$. Anal. Calcd (Found) for $\mathrm{C}_{51} \mathrm{H}_{45} \mathrm{~N}_{3} \mathrm{O}_{12} \cdot \mathrm{CH}_{3} \mathrm{OH}: \mathrm{C}, 67.60$ (67.78); $\mathrm{H}, 5.35$ (5.22); N, 4.55 (4.35).

\section{$N, N^{\prime}, N^{\prime \prime}$-Tris [2-benzyloxy,3-methoxy(benzoyl)carbonyl]cyclotriseryl trilactone, tribenzyl- SER(3M)SAM (5)}

Tris( $N$-hydrochloride--s-serine) trilactone $(0.371 \mathrm{~g}, 1.0 \mathrm{mmol})$ was suspended in $40 \mathrm{~mL}$ of dry and degassed THF and cooled in an ice/water bath. Solutions of 2-(benzyloxy),3(methoxy)benzoyl chloride $(1.38 \mathrm{~g}, 5.0 \mathrm{mmol})$ in $10 \mathrm{~mL}$ of THF and triethylamine $(1.01 \mathrm{~g}$, $10.0 \mathrm{mmol}$ ) were added simultaneously dropwise via syringes over 10 minutes into this suspension while stirring under nitrogen. The mixture was allowed to warm to room temperature and stirred over night. It was then filtered, concentrated, applied to a silica gel column and eluted with $96: 4 \mathrm{CH}_{2} \mathrm{Cl}_{2}: \mathrm{MeOH}$. Fractions were combined and evaporated to a white solid. Yield: $0.62 \mathrm{~g}(63 \%) .{ }^{1} \mathrm{H}$ NMR $\left(400 \mathrm{MHz}, \mathrm{CDCl}_{3}\right): \delta 3.91(\mathrm{~s}, 9 \mathrm{H}), 4.02$ (dd, $J=$ $\left.8.0 \mathrm{~Hz}, J^{\prime}=2.8 \mathrm{~Hz}, 3 \mathrm{H}\right), 4.15\left(\mathrm{dd}, J=4.4 \mathrm{~Hz}, J^{\prime}=6.4 \mathrm{~Hz}, 3 \mathrm{H}\right), 4.87-4.92(\mathrm{~m}, 3 \mathrm{H}), 5.09(\mathrm{~m}$, $6 \mathrm{H}), 7.07-7.45(\mathrm{~m}, 21 \mathrm{H}), 7.64(\mathrm{~d}, J=6.4 \mathrm{~Hz}, 3 \mathrm{H}), 8.47(\mathrm{~d}, J=7.2 \mathrm{~Hz}, 3 \mathrm{H}) \mathrm{ppm}$. (+)FABMS: $\mathrm{m} / \mathrm{z}$ 982.5 $\left(\mathrm{MH}^{+}\right)$. Anal. Calcd (Found) for $\mathrm{C}_{54} \mathrm{H}_{51} \mathrm{~N}_{3} \mathrm{O}_{15}: \mathrm{C}, 66.05(65.92) ; \mathrm{H}$, 5.23 (5.48); N, 4.28 (4.63).

\section{$N, N$, N'-Tris[2-(hydroxybenzoyl)carbonyl]cyclotriseryl trilactone, SERSAM (6)}

Absolute ethanol ( $14 \mathrm{~mL})$ was added to a suspension of tribenzyl-SERSAM (275 mg, 0.3 $\mathrm{mmol}$ ) in $100 \mathrm{~mL}$ of ethyl acetate. The solution was hydrogenated over $10 \% \mathrm{Pd}-\mathrm{C}(55.0 \mathrm{mg})$ at room temperature and atmospheric hydrogen pressure for 24 hours. The reaction mixture was filtered over celite, washed with acetone and evaporated under vacuum. The product was collected as a white powder. Yield: $177 \mathrm{mg}(88 \%) .{ }^{1} \mathrm{H}$ NMR $\left(500 \mathrm{MHz}, \mathrm{MeOD}-d_{4}\right): \delta$ $4.63(\mathrm{~m}, 6 \mathrm{H}), 5.03(\mathrm{t}, J=5.0 \mathrm{~Hz}, 3 \mathrm{H}), 6.88(\mathrm{~m}, 6 \mathrm{H}), 7.38(\mathrm{t}, J=8.0 \mathrm{~Hz}, 3 \mathrm{H}), 7.78(\mathrm{~d}, J=8.0$ $\mathrm{Hz}, 3 \mathrm{H}) \mathrm{ppm} .{ }^{13} \mathrm{C}$ NMR $\left(500 \mathrm{MHz}, \mathrm{MeOD}-d_{4}\right): \delta 52.2,64.5,115.6,116.8,119.0,128.6$, 133.7, 158.8, 168.6, 169.2 ppm. (+)-FABMS: $\mathrm{m} / \mathrm{z} 622\left(\mathrm{MH}^{+}\right)$. Anal. Calcd (Found) for $\mathrm{C}_{30} \mathrm{H}_{27} \mathrm{~N}_{3} \mathrm{O}_{12} .0 .5 \mathrm{EtOH}: \mathrm{C}, 55.77$ (55.79); H, 4.53 (4.31); N, 6.29 (6.05). IR: $v 1749$ s, 1641 $\mathrm{s}, 1604 \mathrm{~s}, 1531 \mathrm{~s} \mathrm{~cm}^{-1}$.

$N, N^{\prime}, N$ '-Tris[2-hydroxy, 3-methoxy(benzoyl)carbonyl]cyclotriseryl trilactone, SER(3M)SAM (7)

Absolute ethanol (14 mL) was added to a suspension of tribenzyl-SER(3M)SAM (610 mg, $0.6 \mathrm{mmol}$ ) in $100 \mathrm{~mL}$ of ethyl acetate. The solution was hydrogenated over 10\% Pd-C (122 $\mathrm{mg}$ ) at room temperature and atmospheric hydrogen pressure for 24 hours. The reaction mixture was filtered over celite, washed with acetone and evaporated under vacuum. The product was collected as a white powder. Yield: $300 \mathrm{mg}(70 \%) .{ }^{1} \mathrm{H}$ NMR $(500 \mathrm{MHz}$, MeOD- $\left.d_{4}\right): \delta 3.87(\mathrm{~s}, 9 \mathrm{H}), 4.64\left(\mathrm{dd}, J=4.0 \mathrm{~Hz}, J^{\prime}=11.5 \mathrm{~Hz}, 6 \mathrm{H}\right), 5.03(\mathrm{t}, J=5.0 \mathrm{~Hz}, 3 \mathrm{H})$, $6.84(\mathrm{t}, J=8.0 \mathrm{~Hz}, 3 \mathrm{H}), 7.10(\mathrm{~d}, J=8.0 \mathrm{~Hz}, 3 \mathrm{H}), 7.40(\mathrm{~d}, J=8.0 \mathrm{~Hz}, 3 \mathrm{H}) \mathrm{ppm} .{ }^{13} \mathrm{C}$ NMR (500 MHz, MeOD- $\left.d_{4}\right): \delta 53.9,56.8,66.0,116.2,117.8,120.2,121.8,149.3,149.6,169.4$, 170.6 ppm. (+)-FABMS: m/z $718\left(\mathrm{MLi}^{+}\right)$. Anal. Calcd (Found) for $\mathrm{C}_{33} \mathrm{H}_{33} \mathrm{~N}_{3} \mathrm{O}_{15}: \mathrm{C}, 55.70$ (56.06); H, 4.67 (5.01); N, 5.90 (5.50). IR: v $1748 \mathrm{~s}, 1642 \mathrm{~s}, 1586 \mathrm{~s}, 1530 \mathrm{~s} \mathrm{~cm}^{-1}$.

\section{$\left[\mathrm{Fe}^{\mathrm{III}}(\mathrm{SERSAM})\right]^{0}(8)$}

To a degassed $\mathrm{MeOH}$ solution of SERSAM (74.4 mg, $0.11 \mathrm{mmol}$ ) was added anhydrous $\mathrm{FeCl}_{3}(19.4 \mathrm{mg}, 0.12 \mathrm{mmol})$ and $0.12 \mathrm{~mL}$ of pyridine. The solution immediately turned dark red, with rapid precipitation of the product as red powder. After the reaction mixture was stirred for $1 \mathrm{~h}$ under nitrogen, the solid was collected by filtration, washed with cold $\mathrm{MeOH}$ and dried overnight. Yield: $76 \mathrm{mg}(91 \%) . \mathrm{Mp}>300^{\circ} \mathrm{C}$. (+)-ESMS: m/z $697.1\left([\mathrm{M}+\mathrm{Na}]^{+}\right)$. Anal. Calcd (Found) for $\mathrm{C}_{30} \mathrm{H}_{24} \mathrm{FeN}_{3} \mathrm{O}_{12} \cdot \mathrm{H}_{2} \mathrm{O} \cdot \mathrm{CH}_{3} \mathrm{OH} \cdot 0.5 \mathrm{HCl}: \mathrm{C}, 48.93$ (48.66); H, 4.04 (3.73); N, 5.52 (5.13). IR: $v 1751 \mathrm{~s}, 1606 \mathrm{~s}, 1574 \mathrm{~s}, 1534 \mathrm{~s} \mathrm{~cm}^{-1}$. 


\section{$\left[\mathrm{Fe}^{\mathrm{III}}\left(\mathrm{SER}(3 \mathrm{M}) \mathrm{SAM}^{\mathrm{O}}\right]^{0}(\mathbf{9})\right.$}

To a degassed $\mathrm{MeOH}$ solution of SER(3M)SAM (100 mg, $0.14 \mathrm{mmol})$ was added anhydrous $\mathrm{FeCl}_{3}(22.7 \mathrm{mg}, 0.14 \mathrm{mmol})$ and $0.55 \mathrm{~mL}$ of pyridine. The solution immediately turned dark purple, with rapid precipitation of the product as purple powder. After the reaction mixture was stirred for $1 \mathrm{~h}$ under nitrogen, the solid was collected by filtration, washed with cold $\mathrm{MeOH}$ and dried overnight. Yield: $68 \mathrm{mg}(63 \%) . \mathrm{Mp}>300{ }^{\circ} \mathrm{C}$. (+)-ESMS: $\mathrm{m} / \mathrm{z} 765.0$ $\left([\mathrm{MH}]^{+}\right.$). Anal. Calcd (Found) for $\mathrm{C}_{33} \mathrm{H}_{30} \mathrm{FeN}_{3} \mathrm{O}_{15} \cdot 0.5 \mathrm{H}_{2} \mathrm{O}: \mathrm{C}, 51.25(51.00) ; \mathrm{H}, 4.04$ (4.42); N, 5.43 (5.36). IR: $v 1754 \mathrm{~s}, 1604 \mathrm{~s}, 1580 \mathrm{~s}, 1536 \mathrm{~s} \mathrm{~cm}^{-1}$.

\section{$\left[\mathrm{Fe}^{\mathrm{III}}(\mathrm{Ent})\right]^{3-}(10)$}

To a degassed $\mathrm{MeOH}$ solution of enterobactin $(50 \mathrm{mg}, 0.075 \mathrm{mmol}$ ) was added a solution of $\mathrm{Fe}(\mathrm{acac})_{3}(26.4 \mathrm{mg}, 0.0750 \mathrm{mmol})$ in degassed $\mathrm{MeOH}$. The solution immediately turned dark purple. A KOH solution in $\mathrm{MeOH}(0.225 \mathrm{mmol})$ was then added via cannula and the solution turned deep red. The solution was taken to dryness and applied to a sephadex LH-20 column in MeOH. The ferric complex eluted as a single red band, which was dried in vacuo to afford a deep red powder. Yield: $42 \mathrm{mg}(58 \%)$. Mp > $300{ }^{\circ} \mathrm{C}$. (-)-ESMS: $\mathrm{m} / \mathrm{z}$ $360.2\left([\mathrm{M}+\mathrm{H}]^{2-}\right)$. Anal. Calcd (Found) for $\mathrm{C}_{30} \mathrm{H}_{21} \mathrm{FeK}_{3} \mathrm{~N}_{3} \mathrm{O}_{15} \cdot 4 \mathrm{H}_{2} \mathrm{O} \cdot 2 \mathrm{MeOH}: \mathrm{C}, 39.51$ (39.61); $\mathrm{H}, 3.83$ (3.70); $\mathrm{N}, 4.32$ (3.95). UV-Vis (5\% DMAA in $\left.\mathrm{H}_{2} \mathrm{O}\right): \lambda=498 \mathrm{~nm}(\varepsilon=5700$ $\left.\mathrm{M}^{-1} \mathrm{~cm}^{-1}\right), 338 \mathrm{~nm}\left(\varepsilon=15100 \mathrm{M}^{-1} \mathrm{~cm}^{-1}\right)$. IR: $v 1752 \mathrm{~s}, 1606 \mathrm{~s}, 1582 \mathrm{~s}, 1539 \mathrm{~s}, 1462 \mathrm{~s}$, $1440 \mathrm{~s}, 1256(\mathrm{sh}), 1218 \mathrm{~s} \mathrm{~cm}^{-1}$.

\section{$\left[\mathrm{Fe}^{\mathrm{III}}\left(\mathrm{H}_{3} \mathrm{Ent}\right)\right]^{0}(11)$}

To a degassed $\mathrm{MeOH}$ solution of enterobactin $(50 \mathrm{mg}, 0.075 \mathrm{mmol}$ ) was added a solution of $\mathrm{Fe}(\mathrm{acac})_{3}(26.4 \mathrm{mg}, 0.0750 \mathrm{mmol})$ in degassed $\mathrm{MeOH}$. The resulting mixture immediately turned dark purple. It was then evaporated to dryness and applied to a sephadex LH-20 column in $\mathrm{MeOH}$. The ferric complex eluted as a single purple band which was dried in vacuo to yield a deep purple powder. Yield: $33 \mathrm{mg}(61 \%)$. Mp: $171-173{ }^{\circ} \mathrm{C} .(-)-E S M S: \mathrm{m} / \mathrm{z}$ $721.1\left([\mathrm{M}-\mathrm{H}]^{-}\right)$. UV-Vis (5\% DMAA in $\left.\mathrm{H}_{2} \mathrm{O}\right): \lambda=309 \mathrm{~nm}\left(\varepsilon=9000 \mathrm{M}^{-1} \mathrm{~cm}^{-1}\right)$. IR: $v 1754$ s, $1640 \mathrm{~s}, 1620 \mathrm{~s}, 1584 \mathrm{~s}, 1547 \mathrm{~s}, 1442 \mathrm{~s}, 1222 \mathrm{~s} \mathrm{~cm}^{-1}$.

\section{$\left[\mathrm{Ga}^{\text {IIII}}(\mathrm{Ent})\right]^{3-}(12)$}

To a degassed $\mathrm{MeOH}$ solution of enterobactin $(66.9 \mathrm{mg}, 0.1 \mathrm{mmol})$ was added a solution of $\mathrm{Ga}(\mathrm{acac})_{3}(36.7 \mathrm{mg}, 0.1 \mathrm{mmol})$ in degassed $\mathrm{MeOH}$. The solution turned slightly yellow. A $\mathrm{KOH}$ solution in $\mathrm{MeOH}(0.3 \mathrm{mmol})$ was then added via cannula. The solution was stirred for 24 hours under $\mathrm{N}_{2}$, taken to dryness and applied to a sephadex LH-20 column in $\mathrm{MeOH}$. The gallic complex eluted as a single yellow band which was dried in vacuo to afford a yellow powder. Yield: $51 \mathrm{mg}(60 \%)$. Mp > $300{ }^{\circ} \mathrm{C} .{ }^{1} \mathrm{H}$ NMR $\left(500 \mathrm{MHz}, \mathrm{DMSO}-d_{6}\right): \delta 3.74$ $(\mathrm{d}, J=11.5 \mathrm{~Hz}, 3 \mathrm{H}), 5.07(\mathrm{~m}, 3 \mathrm{H}), 5.16(\mathrm{~d}, J=11.5 \mathrm{~Hz}, 3 \mathrm{H}), 6.03(\mathrm{t}, J=7.5 \mathrm{~Hz}, 3 \mathrm{H}), 6.18$ (d, $J=1.5 \mathrm{~Hz}, 3 \mathrm{H}), 6.64(\mathrm{~d}, J=1.5 \mathrm{~Hz}, 3 \mathrm{H}), 11.88(\mathrm{~m}, 3 \mathrm{H}) \mathrm{ppm}$. (-)-ESMS: m/z 810.0 ([M-K $\left.]^{-}\right)$. UV-Vis (5\% DMAA in $\left.\mathrm{H}_{2} \mathrm{O}\right): \lambda=346 \mathrm{~nm}\left(\varepsilon=14500 \mathrm{M}^{-1} \mathrm{~cm}^{-1}\right)$. IR: $v 1754 \mathrm{~s}$, $1612 \mathrm{~s}, 1587 \mathrm{~s}, 1540 \mathrm{~s}, 1468 \mathrm{~s}, 1445 \mathrm{~s}, 1257$ (sh), $1217 \mathrm{~s} \mathrm{~cm}^{-1}$.

\section{$\left[\mathrm{Ga}^{\mathrm{III}}\left(\mathrm{H}_{3} \mathrm{Ent}\right)\right]^{0}(13)$}

To a degassed $\mathrm{MeOH}$ solution of $\mathrm{H}_{6}$ (enterobactin) $(66.9 \mathrm{mg}, 0.100 \mathrm{mmol})$ was added a solution of $\mathrm{Ga}(\mathrm{acac})_{3}(36.7 \mathrm{mg}, 0.100 \mathrm{mmol})$ in degassed $\mathrm{MeOH}$. The resulting mixture turned slightly yellow. It was then evaporated to dryness and applied to a sephadex LH-20 column in $\mathrm{MeOH}$. The gallic complex eluted as a single band which was dried in vacuo to yield a beige powder. Yield: $45 \mathrm{mg}(61 \%)$. Mp: $186-187{ }^{\circ} \mathrm{C} .{ }^{1} \mathrm{H}$ NMR $(500 \mathrm{MHz}$, DMSO$\left.d_{6}\right): \delta 3.96$ (br d, $\left.J=10.5 \mathrm{~Hz}, 3 \mathrm{H}\right), 5.07(\mathrm{br}, 3 \mathrm{H}), 5.16(\mathrm{~d}, J=9.0 \mathrm{~Hz}, 3 \mathrm{H}), 6.29(\mathrm{t}, J=7.5$ $\mathrm{Hz}, 3 \mathrm{H}), 6.57$ (br, 3H), 7.01 (br, 3H), 8.89 (br, 3H), 11.22 (br, 3H) ppm. ${ }^{13} \mathrm{C}$ NMR (400 MHz, DMSO- $\left.d_{6}\right): \delta 57.6,62.8,114.3,118.7,119.5,124.2,145.8,163.6,180.1,185.3 \mathrm{ppm}$. 
(-)-ESMS: $\mathrm{m} / \mathrm{z} 734.1$ ([M-H] $\left.{ }^{-}\right)$. UV-Vis (5\% DMAA in $\left.\mathrm{H}_{2} \mathrm{O}\right): \lambda=304 \mathrm{~nm}(\varepsilon=9000$

$\left.\mathrm{M}^{-1} \mathrm{~cm}^{-1}\right)$. IR: $v 1754 \mathrm{~s}, 1641 \mathrm{~s}, 1620 \mathrm{~s}, 1586 \mathrm{~s}, 1548 \mathrm{~s}, 1451 \mathrm{~s}, 1220 \mathrm{~s} \mathrm{~cm}^{-1}$.

\section{Solution Thermodynamics}

Ligands protonation and complex formation constants were determined using procedures and equipment following previous descriptions. ${ }^{46-48}$

\section{Titration Solutions and Equipment}

Corning high performance combination glass electrodes (response to $\left[\mathrm{H}^{+}\right]$was calibrated before each titration $)^{49}$ were used together with either an Accumet $\mathrm{pH}$ meter or a Metrohm Titrino to measure the $\mathrm{pH}$ of the experimental solutions. Metrohm autoburets (Dosimat or Titrino) were used for incremental addition of acid or base standard solutions to the titration cell. The titration instruments were fully automated and controlled using LabView software. ${ }^{50}$ Titrations were performed in $0.1 \mathrm{M} \mathrm{KCl}$ supporting electrolyte under positive $\mathrm{Ar}$ gas pressure. The temperature of the experimental solution was maintained at $25^{\circ} \mathrm{C}$ by an external circulating water bath. UV-Visible spectra for incremental titrations were recorded on a Hewlett-Packard 8452a spectrophotometer (diode array). Solid reagents were weighed on a Metrohm analytical balance accurate to $0.01 \mathrm{mg}$. All titrant solutions were prepared using distilled water that was further purified by passing through a Millipore Milli-Q reverse osmosis cartridge system. Titrants were degassed by boiling for $1 \mathrm{~h}$ while being purged under Ar. Carbonate-free 0.1 M KOH was prepared from Baker Dilut-It concentrate and was standardized by titrating against potassium hydrogen phthalate using phenolphthalein as an indicator. Solutions of $0.1 \mathrm{M} \mathrm{HCl}$ were similarly prepared and were standardized by titrating against sodium tetraborate to Methyl Red endpoint.

\section{Incremental Spectrophotometric Titrations}

The protonation constants of SERSAM and SER(3M)SAM as well as the formation constants of their respective ferric complexes were determined by spectrophotometric titration due to solubility issues. Solutions were assembled from a weighed portion of compound and the supporting electrolyte solution (containing no more than $4 \%$ of $\mathrm{N}, \mathrm{N}$ dimethylacetamide), with resulting ligand (or complex) concentrations between 50 and 100 $\mu \mathrm{M}$. Constant buffering of the solution was assured by the addition of $\mathrm{NH}_{4} \mathrm{Cl}$, Hepes and Mes buffers $(500 \mu \mathrm{M})$. The solutions were incrementally perturbed by the addition of either base ( $\mathrm{KOH}$, ligand titrations) or acid ( $\mathrm{HCl}$, complex titrations) titrant, followed by a time delay for equilibration ( 90 seconds for protonation studies; 2 hours for ferric complex titrations). An average of $40-50$ data points were collected in each ligand titration, each data point consisting of a $\mathrm{pH}$ measurement and an absorbance spectra over the $\mathrm{pH}$ range 4.5 to 10 . An average of 25 data points were collected over the $\mathrm{pH}$ range 2.0 to 5.5 for the ferric complexes. All absorbance measurements used for calculation of formation constants were less than 1.05 absorbance units.

\section{Data Treatment}

All results presented are the average of at least three independent titrations. All equilibrium constants were defined as cumulative formation constants, $\beta_{m l h}$ according to eq. 2 , where the ligands are designated as L. Stepwise protonation constants, $K_{a}^{n}$, may be derived from these cumulative constants according to eq. 3 (describes proton association constants). Nonlinear least squares refinement of the protonation and formation constants was accomplished using the program pHab. ${ }^{27}$ The proton concentration was allowed to vary in the spectrophotometric studies, and all other concentrations were held at estimated values determined from the volume of standardized stock or the weight of ligand (measured to 0.01 $\mathrm{mg}$ ). Refined concentrations were within $5 \%$ of the analytical values. For spectral titrations, 
all species formed with the ligands $L$ were considered to have significant absorbance to be observed in the UV-Vis spectra.

\section{DFT Calculations}

Computational studies were conducted at the Molecular Graphics and Computation Facility, College of Chemistry, University of California, Berkeley. Density functional theory calculations were performed using lacvp**-b3lyp parameters for geometry optimizations, with the computational software Jaguar 5.5. ${ }^{29}$ For a better localization of the minima, the original coordinates before optimization were established from the crystal structures of $\left[\mathrm{V}^{\mathrm{IV}}(\text { Ent })\right]^{2-}(\mathrm{JOSLOS})$ and $\left[\mathrm{Fe}^{\mathrm{III}}(\mathrm{TRENSAM})\right]^{0}$ (HAKQAL) found on the Cambridge data base. $^{23,31}$

\section{Extended X-ray Absorption Fine Structure Measurements}

EXAFS data were collected on the sector 20 bending magnet beamline at the Advanced Photon Source (APS), Argonne National Laboratory, Illinois, USA. To prevent contamination by higher harmonics, a harmonic rejection mirror with an energy cutoff of $11.2 \mathrm{keV}$ was placed in the X-ray beam. A slightly detuned $\mathrm{Si}(111)$ monochromator doublecrystal was used to collect iron K-edge $(7112 \mathrm{eV})$ spectra and the X-ray beam was defined using $1 \times 8 \mathrm{~mm}$ slits in front of the first ion chamber. Samples were run as powders mixed with boron nitride (1:6) in transmission mode to $\mathrm{k}=15 \AA^{-1}$. Nitrogen was used in all ion chambers with $10 \%$ helium added in the first ion chamber. Transmission spectra were analyzed using RSXAP, ${ }^{51,52}$ an r-space fitting and data reduction suite of programs. The pre-edge absorption was removed by fitting the transmission data to a Victoreen formula and the resulting spectra were normalized to unity at the edge step. The post-edge background was removed by subtracting the isolated atom absorption $\left(\mu_{\mathrm{o}}\right)$, obtained from a series of cubic splines. After this subtraction, choice of an energy origin $\left(\mathrm{E}_{0}\right)$ and conversion from energy space to photoelectron wavevector space, selected $\mathrm{k}^{3}$-weighted spectra are shown in Figures 5 and S2. An increase in coordination number $(\mathrm{N})$ would be expected to increase the amplitude in a linear manner at all $\mathrm{k}$ values whereas an increase in disorder $(\sigma)$ would attenuate the EXAFS signal exponentially and the effect would increase exponentially as $\mathrm{k}$ increases. The fitted range of k-values was $2.5-13.1 \AA^{-1}$ for the data collected at $20 \mathrm{~K}$ with an r-space fit from 1.2 to $3 \AA$ giving 14 total degrees of freedom (dof) using Stern's rule (dof $=(2 \times \Delta r \Delta k / \pi)+2) .{ }^{53}$ The amplitude reduction factor, $\mathrm{S}_{0}{ }^{2}$, was estimated to be 0.75 from low-temperature first-shell fits of both experimental samples. The energy origin, $\mathrm{E}_{0}$, was obtained by averaging first-shell fit results over all scans at all temperatures. These values were subsequently fixed and applied to fits over the full fit range. The fitting model included single-scattering shells from first-shell oxygens and second-shell carbons. Final fits generally allowed only five unconstrained variables from a total of fourteen parameters. Photoelectron scattering amplitudes and phase shifts were calculated using the FEFF7 code $^{54}$ and crystal structures of $\left[\mathrm{Fe}^{\mathrm{III}}(\text { TRENSAM) }]^{0}\right.$ and $\left[\mathrm{Fe}^{\mathrm{III}} \text { (TRENCAM) }\right]^{3-.23,26}$

\section{pD - ${ }^{1} \mathrm{H}$ NMR Spectroscopic Titration}

A combination electrode (Corning) filled with $3 \mathrm{M} \mathrm{KCl}$ (Corning filling solution) was calibrated in water by a strong acid / strong base titration. A solution of $1 \mathrm{mM}\left[\mathrm{Ga}^{\mathrm{III}}(\mathrm{Ent})\right]^{3-}$, $0.1 \mathrm{M} \mathrm{KCl}$ and $1 \mathrm{mM}$ 3-(trimethylsilyl)-1-propanesulfonic acid (DSS) shift agent in $\mathrm{D}_{2} \mathrm{O}$ was prepared and titrated by addition of $\mathrm{DCl}$ with values of $\mathrm{pD}$ calculated according to the relationship $\mathrm{pD}=0.4+\mathrm{pH} .{ }^{28}$ Aliquots of $0.450 \mathrm{~mL}$ each were retrieved after each $\mathrm{DCl}$ addition. ${ }^{1} \mathrm{H}$ NMR spectra of each aliquot were performed on a Brucker Avance AV-500 $\mathrm{MHz}$ equipped with a TBI probe, using a pulse angle of $90^{\circ}$ and 128 scans per sample. Chemical shifts were referenced to the $\mathrm{CH}_{3}$-Si peak of DSS $(0.000 \mathrm{ppm})$. Protonation constants were determined by non-linear least-squares refinement using the program HypNMR $^{55}$ with an estimated uncertainty in chemical shift of $0.01 \mathrm{ppm}$ and corrected for 
the deuterium effect after the refinement according to the correlation $\log \mathrm{K}^{\mathrm{D}}=0.32+1.044$ $\log \mathrm{K}^{\mathrm{H}} \cdot{ }^{28}$

\section{NOE Growth Rates}

Samples of $\left[\mathrm{Ga}^{\mathrm{III}}(\mathrm{Ent})\right]^{3-}$ and $\left[\mathrm{Ga}^{\mathrm{III}}\left(\mathrm{H}_{3} \text { Ent }\right)\right]^{0}$ were prepared as $0.1 \mathrm{M}$ solutions in DMSO$d_{6}$. 2D NOESY spectra were recorded at $348.1 \mathrm{~K}$ on a Bruker Avance AV 500 spectrometer, with varying mixing times $(150,300,400,500,600,700,850$ and $1000 \mathrm{~ms})$. NOE cross peak intensity was plotted versus mixing time $\left(\tau_{m}\right)$. Using the diagonal peaks for each proton as references, the relative NOE growth rates $\sigma$ for the distances of interest could be evaluated, according to $r_{A B}=r_{X Y} \times\left(\sigma_{X Y} / \sigma_{A B}\right)^{1 / 6}$. 41

\section{Electrochemical Measurements}

Cyclic voltammograms of $0.3 \mathrm{mM}$ ferric complex solutions in acetonitrile containing $0.1 \mathrm{M}$ tetrabutylammonium hexafluorophosphate (Fluka, electrochemical grade) as supporting electrolyte were recorded on a BAS100A electrochemical analyzer. Working and auxiliary platinum electrodes were used with a freshly prepared Pleskow reference electrode $(0.01 \mathrm{M}$ $\mathrm{AgNO}_{3}$ in $0.1 \mathrm{M} \mathrm{N}(t-\mathrm{Bu})_{4} \cdot \mathrm{PF}_{6}$ in $\left.\mathrm{CH}_{3} \mathrm{CN} / \mathrm{Ag}\right)$. The half-wave potentials were also measured against the ferrocinium/ferrocene internal reference electrode.

\section{Supplementary Material}

Refer to Web version on PubMed Central for supplementary material.

\section{Acknowledgments}

This research was supported by the National Institutes of Health (Grant AI11744-28). The authors thank Dr. K. Durkin for assistance with the computational studies (NSF CHE-0233882) and Dr. H. van Halbeek for help with the NMR experiments. Use of the Advanced Photon Source was supported by the U. S. Department of Energy (DOE), Office of Science, Office of Basic Energy Sciences, under Contract No. W-31-109-ENG-38. The authors thank Steve Heald and the staff of PNC Sector 20 bend magnet beamline for their assistance. JAW and DKS are supported by the Director, Office of Science, Office of Basic Energy Sciences, Division of Chemical Sciences, Geosciences, and Biosciences of the U.S. Department of Energy at Lawrence Berkeley National Laboratory under Contract No. DE-AC02-05CH11231.

\section{References}

1. Coordination Chemistry of Microbial Iron Transport. 75. Part 74: Dertz EA, Raymond KN. Inorg. Chem. 2006 In Press.

2. Raymond KN, Dertz EA, Kim SS. Proc. Natl. Acad. Sci. USA. 2003; 100:3584-3588. [PubMed: 12655062]

3. Earhart, CF. Iron Transport in Bacteria: Molecular Genetics, Biochemistry, Microbial Pathogenesis and Ecology. Crosa, JH.; Payne, SM., editors. Washington, D.C.: ASM Press; 2004. p. 133-146.

4. Walsh, CT.; Marshall, CG. Iron Transport in Bacteria: Molecular Genetics, Biochemistry, Microbial Pathogenesis and Ecology. Crosa, JH.; Payne, SM., editors. Washington, D.C.: ASM Press; 2004. p. 18-37.

5. Boukhalfa H, Crumbliss AL. BioMetals. 2002; 15:325-339. [PubMed: 12405526]

6. Dertz, EA.; Raymond, KN. Comprehensive Coordination Chemistry - II. McCleverty, J.; Meyer, T., editors. Vol. Vol. 8. Oxford: Pergamon; 2003. p. 141-168.

7. Hantke K. Curr. Opin. Microbiol. 2001; 4:172-177. [PubMed: 11282473]

8. Raymond, KN.; Dertz, EA. Iron Transport in Bacteria: Molecular Genetics, Biochemistry, Microbial Pathogenesis and Ecology. Crosa, JH.; Payne, SM., editors. Washington, D.C.: ASM Press; 2004. p. 3-17. 
9. Raymond, KN.; Telford, JR. Bioinorganic Chemistry An Inorganic Perspective of Life.

Kessissoglou, DP., editor. Vol. Vol. 459. The Netherlands: Kluwer Academic Publishers; 1995. p. 25-37.

10. Goetz DH, Holmes MA, Borregaard N, Bluhm ME, Raymond KN, Strong RK. Mol. Cell. 2002; 10:1033-1043. [PubMed: 12453412]

11. Fischbach MA, Lin H, Liu DR, Walsh CT. Nature Chem. Biol. 2006; 2:132-138. [PubMed: 16485005]

12. Luo M, Lin H, Fischbach MA, Liu DR, Walsh CT, Groves JT. ACS Chem. Biol. 2006; 1:29-32. [PubMed: 17163637]

13. Loomis LD, Raymond KN. Inorg. Chem. 1991; 30:906-911.

14. Brickman TJ, McIntosh MA. J. Biol. Chem. 1992; 267:12350-12355. [PubMed: 1534808]

15. Lin H, Fischbach MA, Liu DR, Walsh CT. J. Am. Chem. Soc. 2005; 127:11075-11084. [PubMed: 16076215]

16. Ecker DJ, Matzanke BF, Raymond KN. J. Bacteriol. 1986; 167:666-673. [PubMed: 2942532]

17. Heidinger S, Braun V, Pecoraro VL, Raymond KN. J. Bacteriol. 1983; 153:109-115. [PubMed: 6217190]

18. Cooper SR, McArdle JV, Raymond KN. Proc. Natl. Acad. Sci. USA. 1978; 75:3551-3554. [PubMed: 151277]

19. Harris WR, Carrano CJ, Cooper SR, Sofen SR, Avdeef AE, McArdle JV, Raymond KN. J. Am. Chem. Soc. 1979; 101:6097-6104.

20. Lee CW, Ecker DJ, Raymond KN. J. Am. Chem. Soc. 1985; 107:6920-6923.

21. Cass ME, Garrett TM, Raymond KN. J. Am. Chem. Soc. 1989; 111:1677-1682.

22. Pecoraro VL, Harris WR, Wong GB, Carrano CJ, Raymond KN. J. Am. Chem. Soc. 1983; 105:4623-4633.

23. Cohen SM, Meyer M, Raymond KN. J. Am. Chem. Soc. 1998; 120:6277-6286.

24. Cohen SM, Raymond KN. Inorg. Chem. 2000; 39:3624-3631. [PubMed: 11196825]

25. Ratledge C, Dover LG. Annu. Rev. Microbiol. 2000; 54:881-941. [PubMed: 11018148]

26. Stack TDP, Karpishin TB, Raymond KN. J. Am. Chem. Soc. 1992; 114:1512-1514.

27. Gans P, Sabatini A, Vacca A. Ann. Chim. (Rome). 1999; 89:45-49.

28. Perrin, DD.; Dempsey, B.; Hall, Ca, editors. London: 1974.

29. Jaguar 5.5. 5.0.1 ed.. Portland, OR: Schrodinger, L.L.C.; 2003.

30. Meyer M, Trowitzsch-Kienast W. Res. Devel. Phys. Chem. 2004; 7:127-149.

31. Karpishin TB, Raymond KN. Angew. Chem. Int. Ed. 1992; 31:466-468.

32. Karpishin TB, Gebhard MS, Solomon EI, Raymond KN. J. Am. Chem. Soc. 1991; 113:2977-2984.

33. Paulsen H, Grunsteudel W, Meyer-Klaucke W, Gerdan M, Grunsteudel HF, Chumakov AI, Ruffer

R, Winkler H, Toftlund H, Trautwein AX. Eur. Phys. J. B. 2001; 23:463-472.

34. Pecoraro VL, Wong GB, Kent TA, Raymond KN. J. Am. Chem. Soc. 1983; 105:4617-4623.

35. Spartalian K, Oosterhuis WT, Neilands JB. J. Chem. Phys. 1975; 62:3538-3543.

36. Sevillano E, Meuth H, Rehr J. J. Phys. Rev. B. 1979; 20:4908-4911.

37. Stern, EA. X-Ray Absorption. New York: Wiley; 1988.

38. Scherk CG, Ostermann A, Achterhold K, Iakovleva O, Nazikkol C, Krebs B, Knapp EW, Meyer-

Klaucke W, Parak FG. Eur. Biophys. J. 2001; 30:393-403. [PubMed: 11718291]

39. Boyce JB, Bridges F, Claeson T, Nygren M. Phys. Rev. B. 1989; 39:6555-6566.

40. Llinas M, Wilson DM, Neilands JB. Biochemistry. 1973; 12:3836-3843. [PubMed: 4745649]

41. Kumar A, Wagner G, Ernst RR, Wutrich K. J. Am. Chem. Soc. 1981; 103:3654-3658.

42. Gagne RR, Koval CA, Lisensky GC. Inorg. Chem. 1980; 19:2854-2855.

43. Marcus YP. App. Chem. 1983; 55:977-1021.

44. Rodgers SJ, Lee CW, Ng CY, Raymond KN. Inorg. Chem. 1987; 26:1622-1625.

45. Meyer M, Telford JR, Cohen SM, White DJ, Xu J, Raymond KN. J. Am. Chem. Soc. 1997; 119:10093-10103.

46. Cohen SM, O'Sullivan B, Raymond KN. Inorg. Chem. 2000; 39:4339-4346. [PubMed: 11196930] 
47. Johnson AR, O'Sullivan B, Raymond KN. Inorg. Chem. 2000; 39:2652-2660. [PubMed: 11197022]

48. Xu J, O'Sullivan B, Raymond KN. Inorg. Chem. 2002; 41:6731-6742. [PubMed: 12470069]

49. Gans P, O'Sullivan B. Talanta. 2000; 51:33-37. [PubMed: 18967834]

50. LABVIEW. 5.0.1 ed.. Austin, TX: National Instruments Corp.;

51. Hayes TM, Boyce JB. Solid State Phys. Adv. Res. App. 1982; 37:173-351.

52. Li GG, Bridges F, Booth CH. Phys. Rev. B. 1995; 521:6332-6348.

53. Stern EA. Phys. Rev. B. 1993; 48:9825-9827.

54. Zabinsky SI, Rehr JJ, Ankudinov A, Albers RC, Eller M. J. Phys. Rev. B. 1995; 52:2995-3009.

55. Gans P. Protonic Software. 1999 


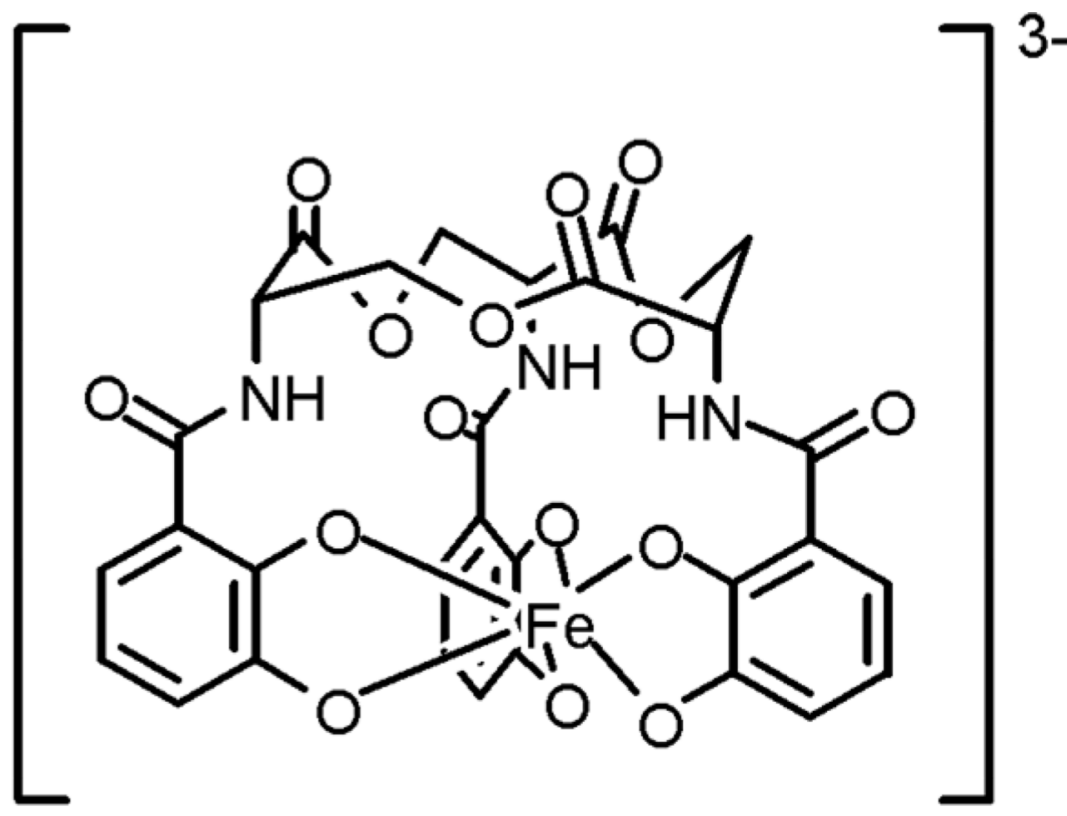

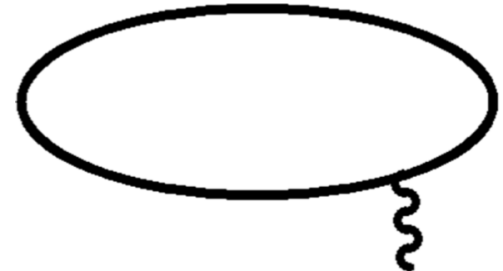
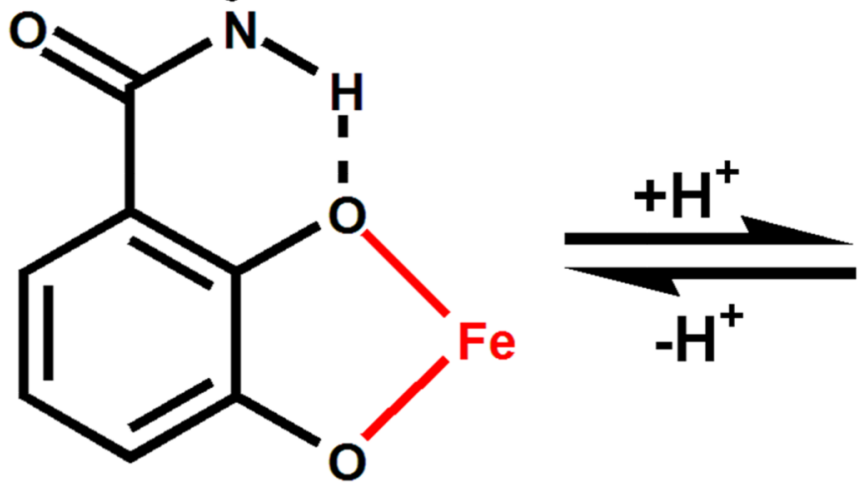

Figure 1.

Ferric enterobactin (top) and the coordination shift from catecholate (bottom left) to salicylate (bottom right) upon protonation. 


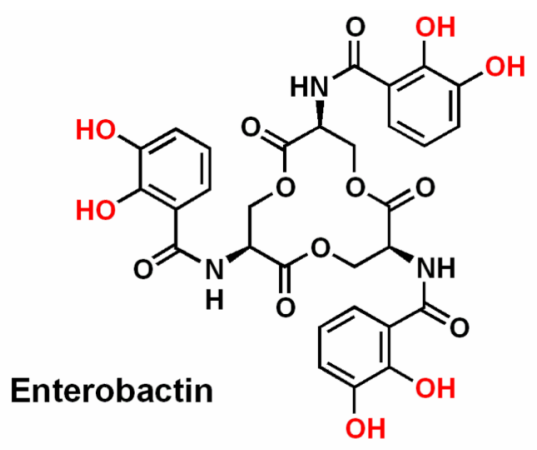<smiles>C[R16]#[R5]=S</smiles>

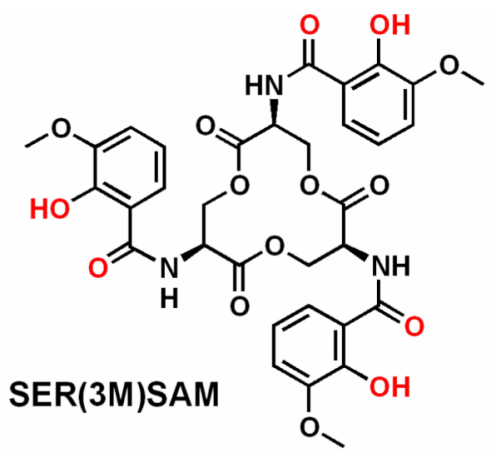<smiles>CN(C)[N+]([O-])=C=[In]</smiles><smiles>CC(C)NS(=O)(=O)NCc1ccccc1</smiles><smiles>COc1cccc(C(=O)NCCN(CCNC(=O)c2cccc(OC)c2O)CCNC(=O)c2cccc(OC)c2O)c1O</smiles>

Figure 2.

Enterobactin and its synthetic analogs: the catecholate TRENCAM and salicylate SERSAM, SER(3M)SAM, TRENSAM and TREN(3M)SAM ligands. The coordinating oxygen atoms are indicated in red. 

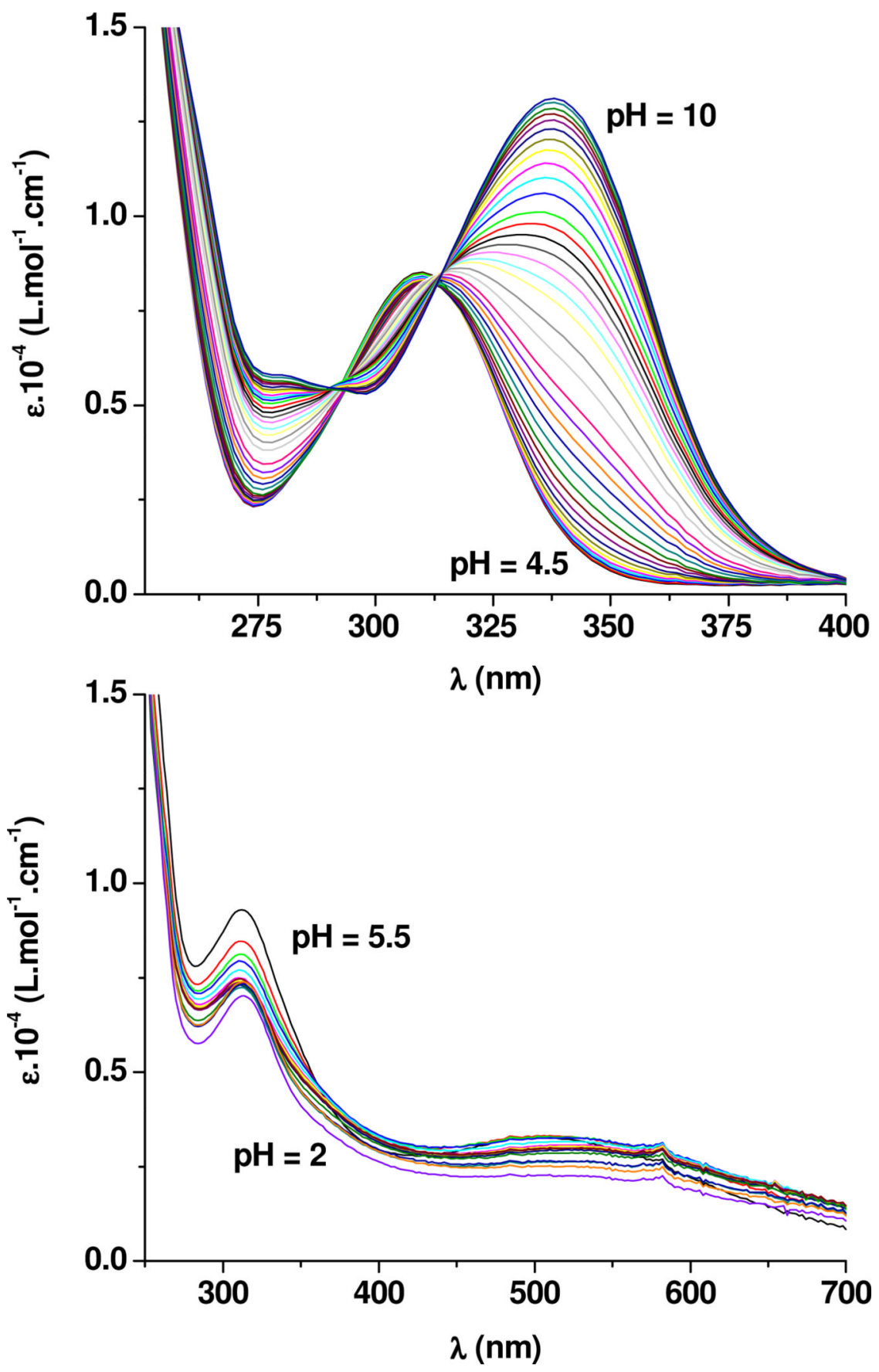

Figure 3.

Spectrophotometric titrations of SER(3M)SAM by KOH (top) and [Fe $\left.{ }^{\mathrm{III}}(\mathrm{SER}(3 \mathrm{M}) \mathrm{SAM})\right]^{0}$ by $\mathrm{HCl}$ (bottom) in water. $I=0.1(\mathrm{KCl}), T=25.0{ }^{\circ} \mathrm{C}, l=1 \mathrm{~cm}$. 

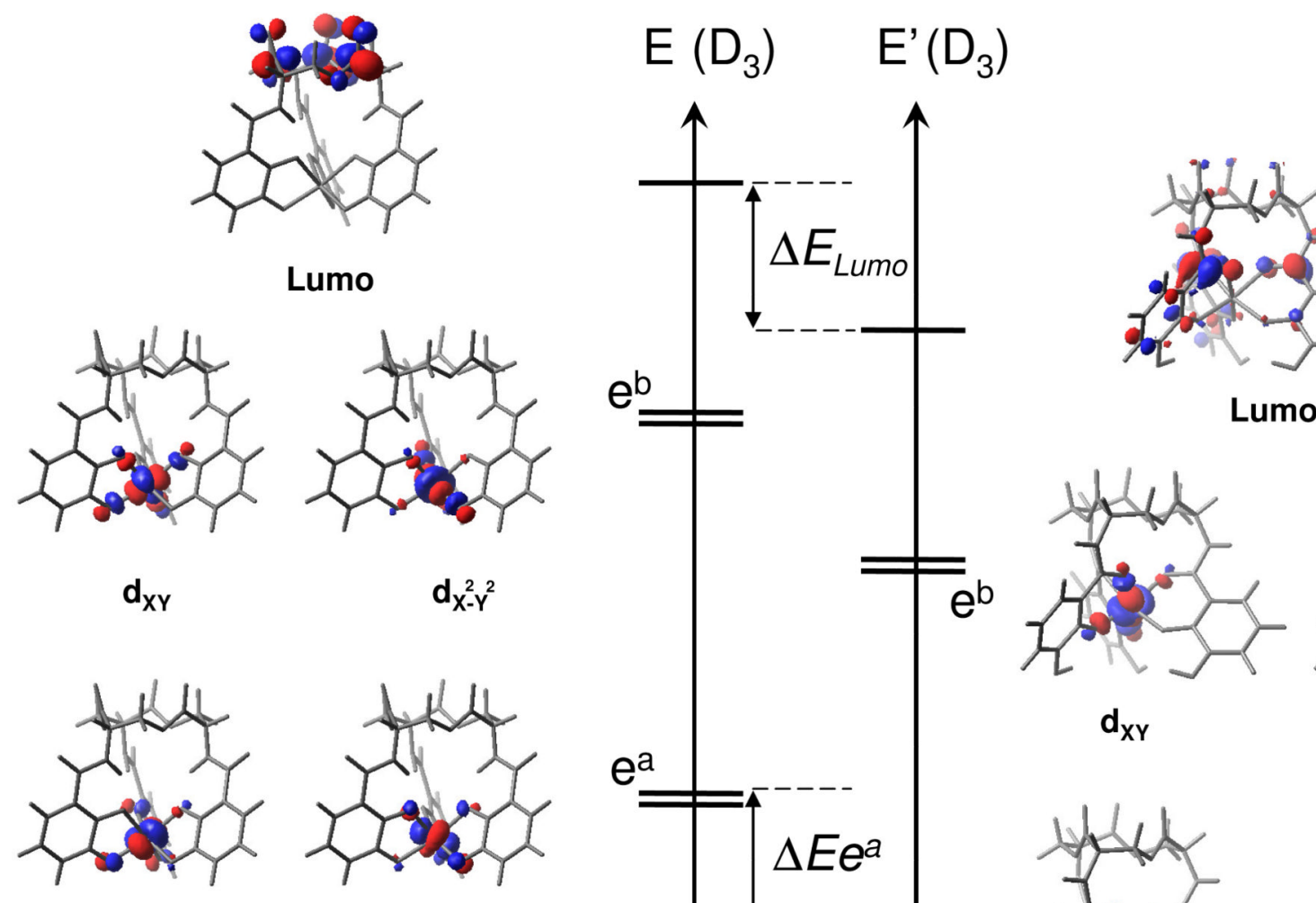

$$
\mathbf{d}_{\mathrm{XY}}
$$
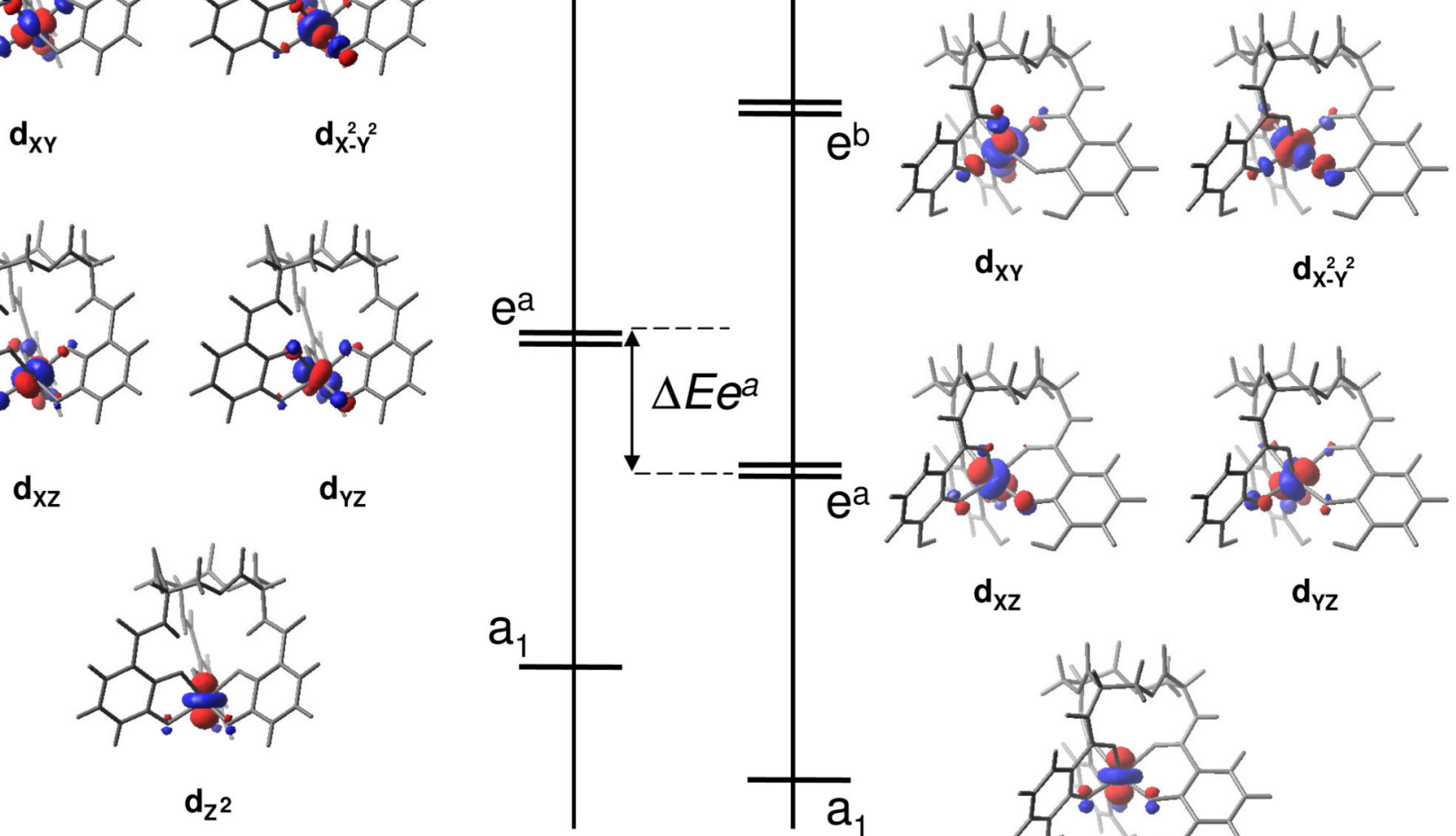

$d_{Y Z}$

Figure 4.

Calculated frontier molecular orbital energy level diagrams for $\left[\mathrm{Fe}^{\mathrm{III}}(\mathrm{Ent})\right]^{3-}(\mathrm{left})$ and sal$\left[\mathrm{Fe}^{\mathrm{III}}\left(\mathrm{H}_{3} \mathrm{Ent}\right)\right]^{0}$ (right). 

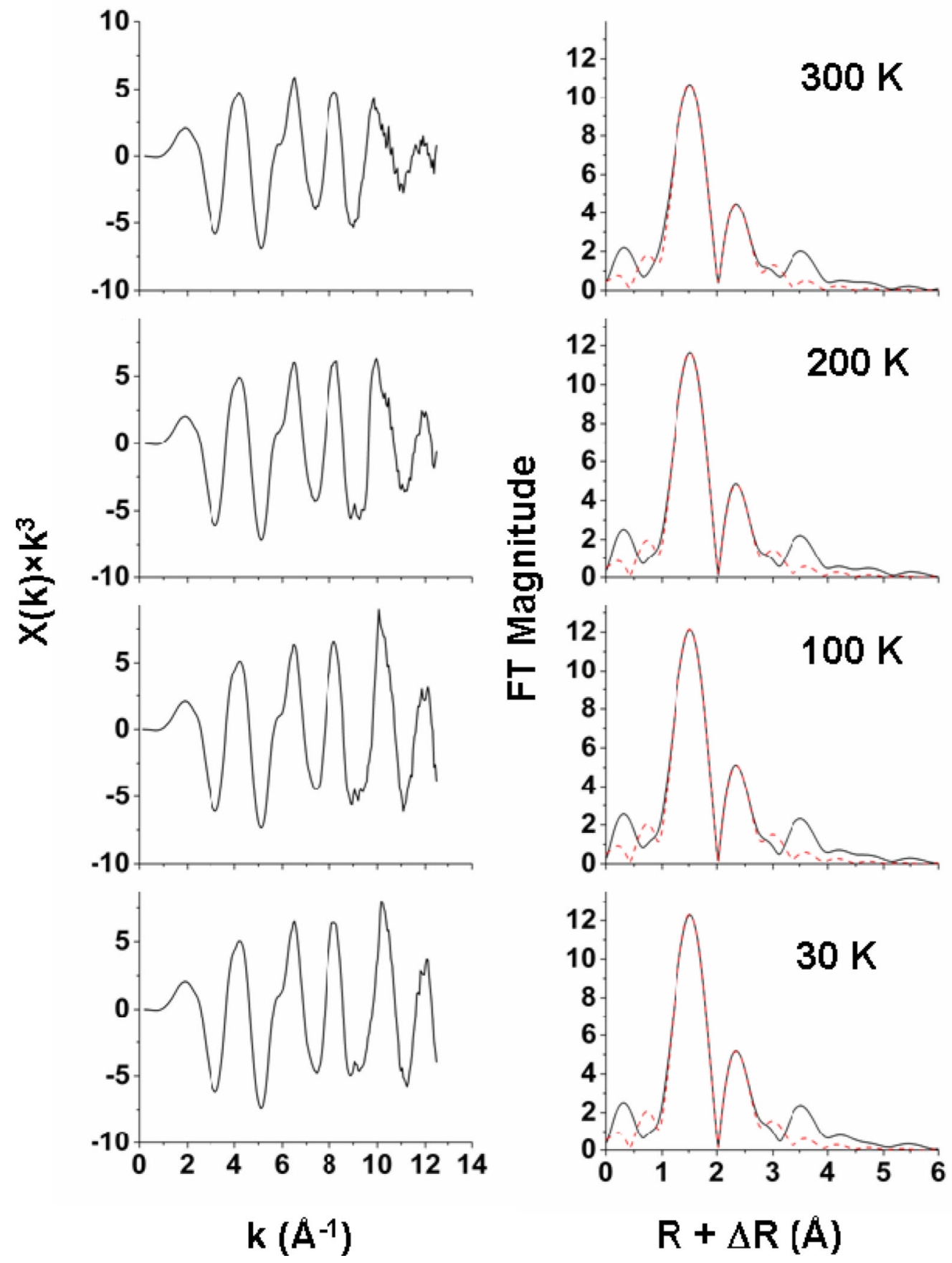

Figure 5.

k-space spectra (left), Fourier transforms (right, solid lines) and R-space fits (right, dashed lines) of $\left[\mathrm{Fe}^{\mathrm{III}}(\mathrm{Ent})\right]^{3-}$ at 30, 100, 200 and $300 \mathrm{~K}$. 


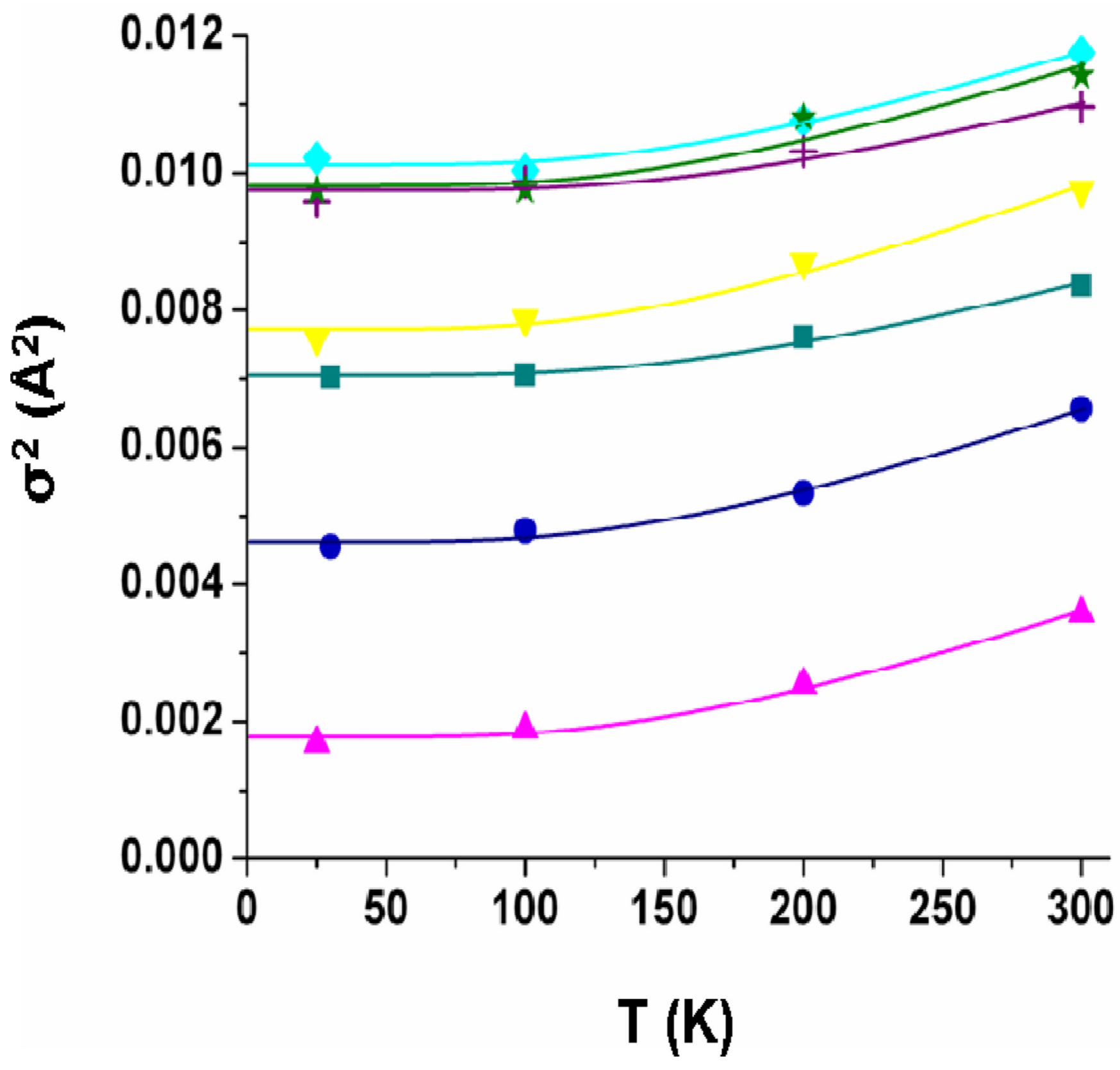

Figure 6.

Einstein model fits of first-shell oxygens for: $\left[\mathrm{Fe}^{\mathrm{III}}(\mathrm{TREN}(3 \mathrm{M}) \mathrm{SAM})\right]^{0},\left[\mathrm{Fe}^{\mathrm{III}}(\mathrm{SERSAM})\right]^{0}$, $\left[\mathrm{Fe}^{\mathrm{III}}(\mathrm{SER}(3 \mathrm{M}) \mathrm{SAM})\right]^{0},\left[\mathrm{Fe}^{\mathrm{III}}(\mathrm{TRENSAM})\right]^{0},\left[\mathrm{Fe}^{\mathrm{III}}\left(\mathrm{H}_{3} \mathrm{Ent}\right)\right]^{0},\left[\mathrm{Fe}^{\mathrm{III}}(\text { Ent })\right]^{3-}$ and $\left[\mathrm{Fe}^{\mathrm{III}}(\mathrm{TRENCAM})\right]^{3-}$ from top to bottom. 


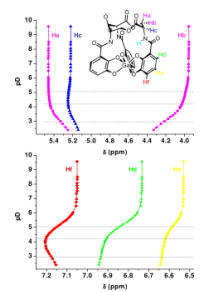

Figure 7.

Variation of the ${ }^{1} \mathrm{H}$ NMR chemical shift as a function of $\mathrm{pD}$ for gallic enterobactin (symbols). Solid lines represent the fitted data. Dashed lines designate the $\mathrm{p} K_{a}$ values of the complex. 


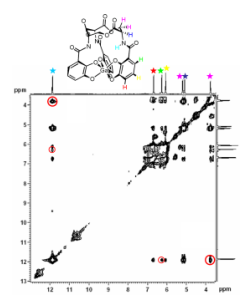

Figure 8.

The $2 \mathrm{D}{ }^{1} \mathrm{H}$ NMR NOESY spectrum of $\left[\mathrm{Ga}^{\mathrm{III}}(\text { Ent })\right]^{3-}(0.1 \mathrm{M})$ in DMSO- $d_{6}, \tau_{m}=0.7 \mathrm{~s}$. Selected NOEs are indicated in red. 

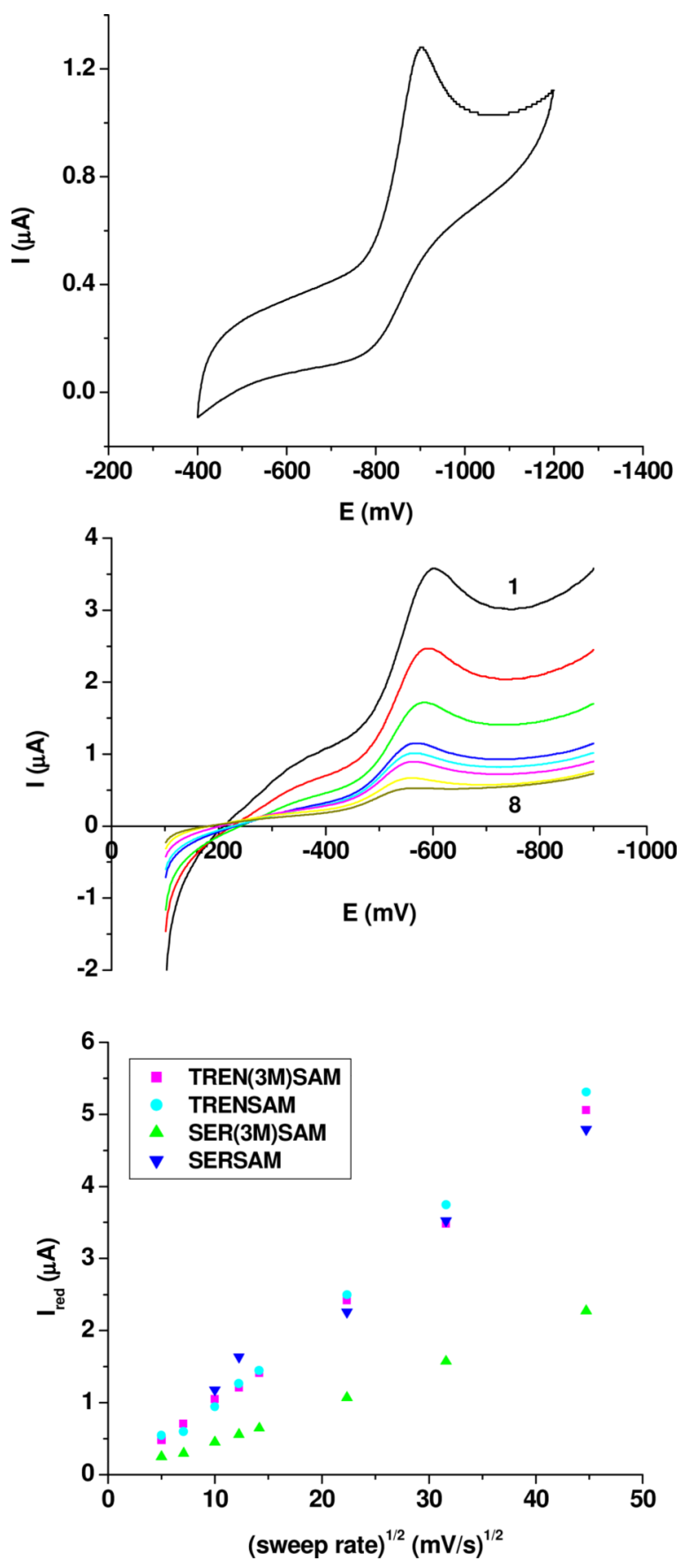

Figure 9.

Cyclic voltammogram of $\left[\mathrm{Fe}^{\mathrm{III}}(\mathrm{TREN}(3 \mathrm{M}) \mathrm{SAM}]^{0}\right.$ at $50 \mathrm{mV} / \mathrm{s}$ (top), reduction wave for $\left[\mathrm{Fe}^{\mathrm{III}}(\mathrm{SER}(3 \mathrm{M}) \mathrm{SAM}]^{0}\right.$ at different scan rates -2000 to $25 \mathrm{mV} / \mathrm{s}$ for spectra 1 to 8 (middle), sweep rate dependence of the reduction current peak for all complexes (bottom). 


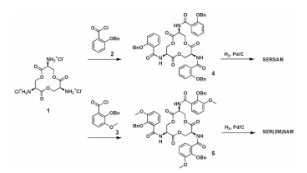

Scheme 1.

Synthesis of the two salicylate analogs of enterobactin SERSAM and SER(3M)SAM. 
Table 1

Refined Protonation and Ferric Complex Formation Constants for SERSAM and SER(3M)SAM. ${ }^{a}$

\begin{tabular}{lccc}
\hline & & \multicolumn{2}{c}{$\log \boldsymbol{\beta}_{\text {mlh }}$} \\
\cline { 3 - 4 } Species & m I h & SERSAM & SER(3M)SAM \\
\hline LH & 011 & $9.1(1)$ & $8.8(1)$ \\
$\mathrm{LH}_{2}$ & 012 & $17.5(2)$ & $16.7(1)$ \\
$\mathrm{LH}_{3}$ & 013 & $23.3(2)$ & $23.3(2)$ \\
$\mathrm{FeL}$ & 110 & $39(3)$ & $38(2)$ \\
\hline
\end{tabular}

${ }^{a} I=0.1(\mathrm{KCl}), T=25^{\circ} \mathrm{C}$. Figures in parentheses give the uncertainty determined from the standard deviation between three independent titrations. 


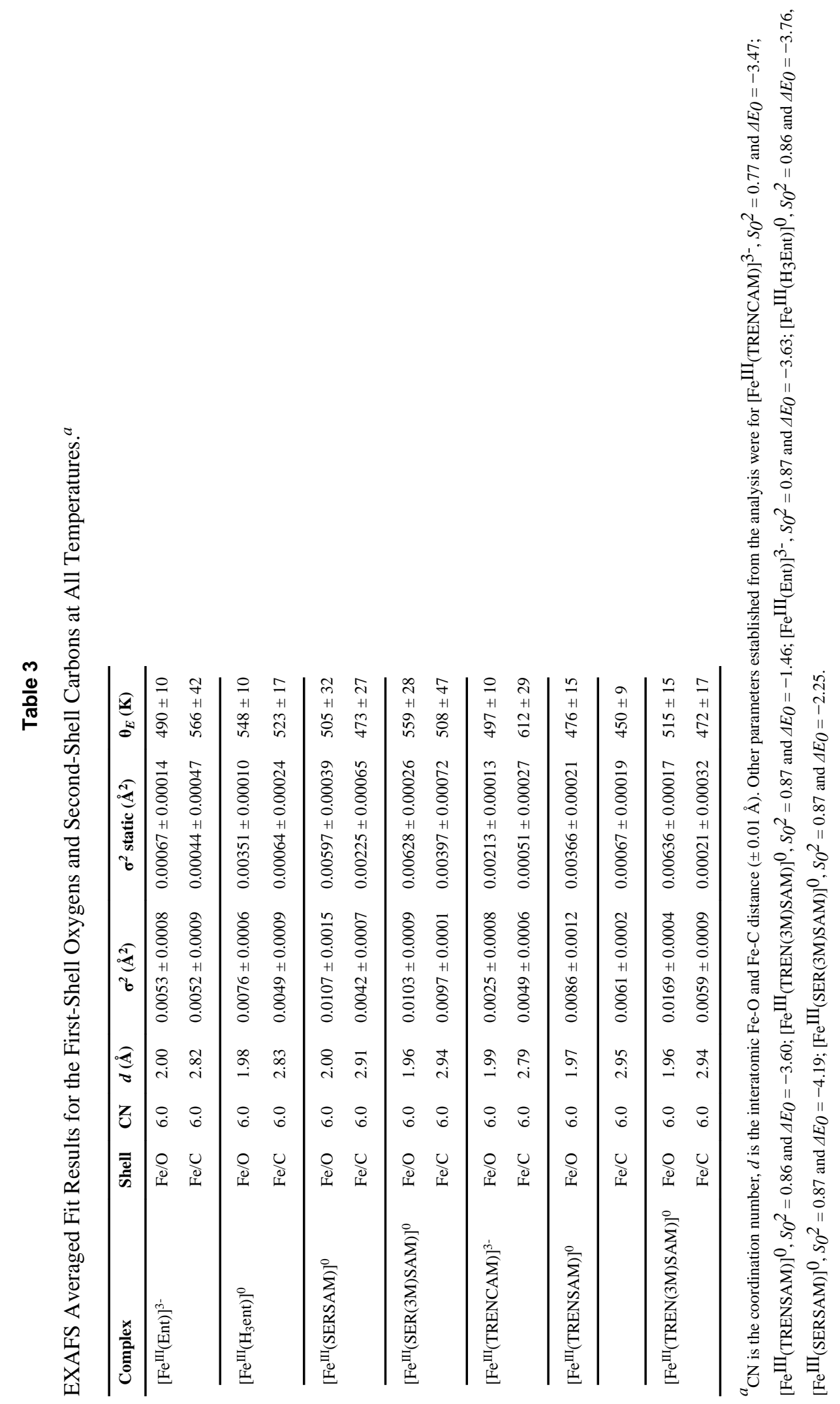


